\title{
17 Furtum Sacrilegum: The 'Holy Heads' of Peter and Paul and Their Reliquaries in the Lateran
}

\author{
DANIELA MONDINI
}

In what follows here, I shall be outlining the processes involved in the revaluation, 'iconisation' and 'image loss' associated with the Sacred Heads of Peter and Paul. ${ }^{1}$ The heads represent an important reliquary complex in the Lateran over a period of several centuries (the basis for the analysis is provided by an extensive range of treatises written by Christian antiquaries, including the main authors Soresini (1673) and Cancellieri (1806)). ${ }^{2}$ After a description of the lost late Gothic reliquaries, I shall go on to discuss a little-known, similarly lost fresco cycle in the north transept of the Lateran basilica, which commemorated a notorious event: the theft of several jewels from the reliquaries of Peter and Paul and the punishment assigned to the perpetrators.

To anticipate the conclusion: the two half-length busts that can be seen today in the monumental late Gothic tabernacle above the main altar of Saint John Lateran, in 'constant ostension' (Figs 17.1 and 17.2), are only a modest replacement, dating from the early nineteenth century, for the formerly much more magnificent late Gothic bust reliquaries. These goldsmithing works, made to the highest standards, dated from a joint endowment by the French pope Urban V (Guillaume de Grimoard), who had brought the Curia back from Avignon to Rome for a short period in 1368 (Fig. 17.3). The king of

\footnotetext{
1 I am grateful to Michel Robertson for his very accurate translation. I have discussed the dynamics of display and concealment in ritual in greater detail in an earlier essay: see D. Mondini, 'Reliquie incarnate: Le "sacre teste" di Pietro e Paolo a San Giovanni in Laterano a Roma', in D. Scotto (ed.), Del visibile credere: Pellegrinaggi, santuari, miracoli, reliquie (Florence, 2011), 265-96; see now also C. D’Alberto, Roma al tempo di Avignone: Sculture nel contesto (Rome, 2013), 147-97.

2 J. M. Soresini, De capitibus sanctorum apostolorum Petri et Pauli in sacrosancta lateranensi ecclesia (Rome, 1673); see also the shorter Italian edition by the same author, Compendio istorico cronologico delle cose più cospique concernenti la Scala Santa e le SS. Teste (Rome, 1674). Later authors who also refer back to Soresini include A. Baldeschi and G. Crescimbeni, Stato della SS. chiesa papale lateranense nell'anno MDCCXXIII (Rome, 1723), 96-119; G. Marangoni, Istoria dell'antichissimo oratorio, o cappella di San Lorenzo nel Patriarchio Lateranense comunemente appellato Sancta Sanctorum (Rome, 1747), 260-4; [F. Cancellieri], Memorie istoriche delle sacre teste de' santi Apostoli Pietro e Paolo e della loro solenne ricognizione nella basilica lateranense (Rome, 1806).
} 


\section{CAMBRIDGE}

\section{Cambridge University Press}

978-1-108-83976-1 - The Basilica of Saint John Lateran to 1600

Edited by L. Bosman , I. P. Haynes, P. Liverani

More Information



Fig. 17.1 San Giovanni in Laterano, main altar tabernacle by Giovanni di Stefano, 1370 (Photo: author).

France, Charles V, and prominent members of other royal houses also contributed to the endowment (the queen of Naples, Joanna of Anjou (1343-82) and Joan of France (1355-73), sister of the French king and 
Cambridge University Press

978-1-108-83976-1 - The Basilica of Saint John Lateran to 1600

Edited by L. Bosman , I. P. Haynes , P. Liverani

More Information

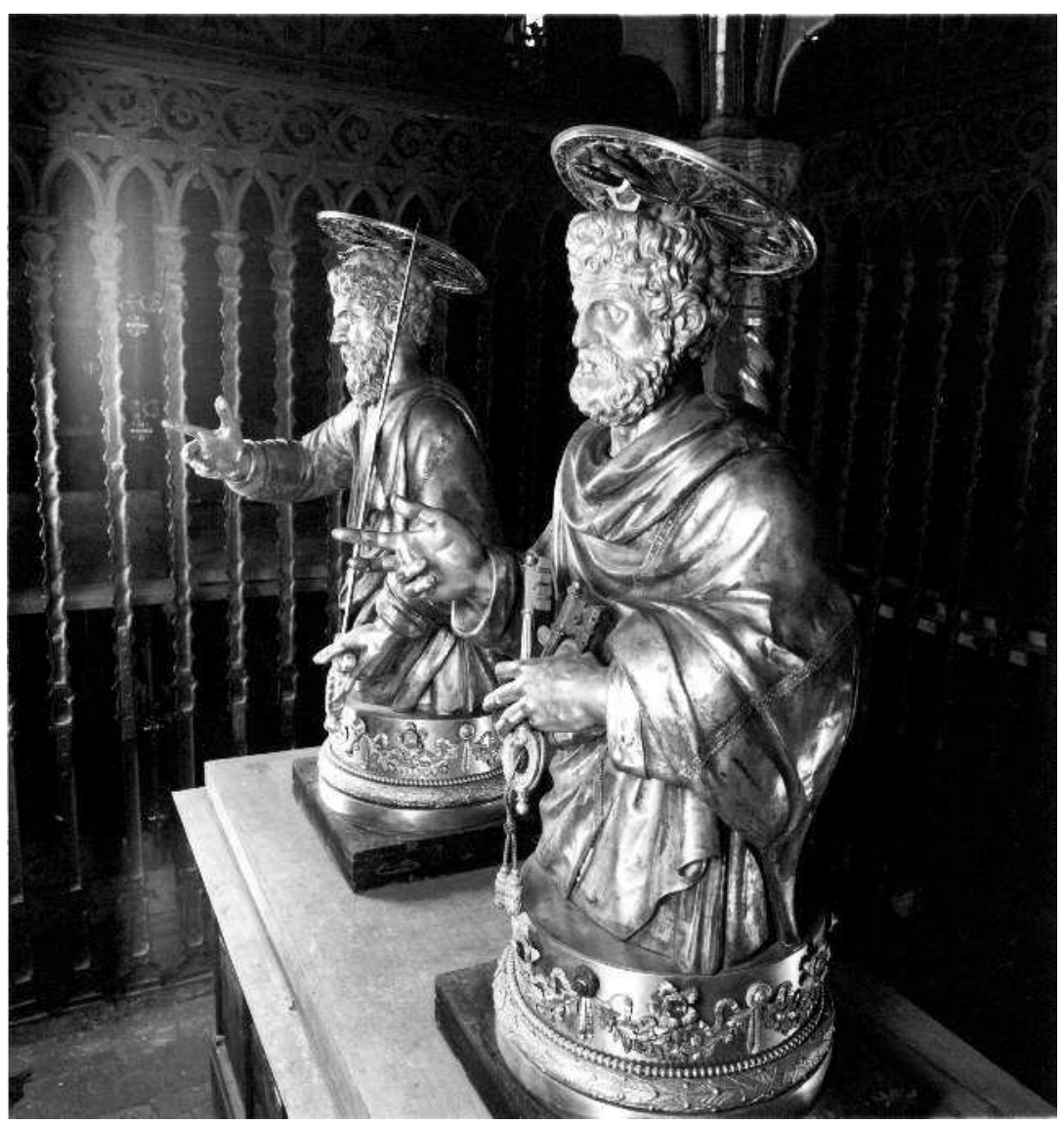

Fig. 17.2 San Giovanni in Laterano, the reliquaries of the 'Holy Heads' of Peter and Paul, enclosed in the tabernacle; Giuseppe Valadier and Workshop, 1804 (Photo: Archivio fotografico Musei Vaticani).

consort of Charles II of Navarre). ${ }^{3}$ From 1370 to 1798 the reliquaries remained enclosed in the upper storey of the monumental main altar ciborium, which was specially constructed for the purpose. ${ }^{4}$

3 The collective endowment is mentioned in the files for the unsuccessful canonisation of Urban V (Archivio Segreto Vaticano, fol. 123, cited in Soresini, De capitibus, 6 and Cancellieri, Memorie, 20; however, this document can now no longer be located and is missing from the document collection by J. H. Albanès and U. Chevalier, Actes anciens et documents concernant le bienheureux Urbain V pape, sa famille, sa personne, son pontificat, ses miracles et son culte (Paris, 1897). I have not yet found any evidence in the sources for the possible involvement of Emperor Charles IV of Bohemia, who was staying in Rome in the autumn of 1368 (see J. M. Fritz, Goldschmiedekunst der Gotik in Mitteleuropa (Munich, 1982), 222-3 fig. 260); I regard it as a case of mistaken identity.

${ }^{4}$ A. Monferini, 'Il ciborio Lateranense e Giovanni di Stefano', Commentari. Rivista di Critica e Storia dell'Arte, n.s., 13, 3.4 (1962), 182-212; D’Alberto, Roma al tempo di Avignone, 166-79. 
Cambridge University Press

978-1-108-83976-1 - The Basilica of Saint John Lateran to 1600

Edited by L. Bosman, I. P. Haynes, P. Liverani

More Information

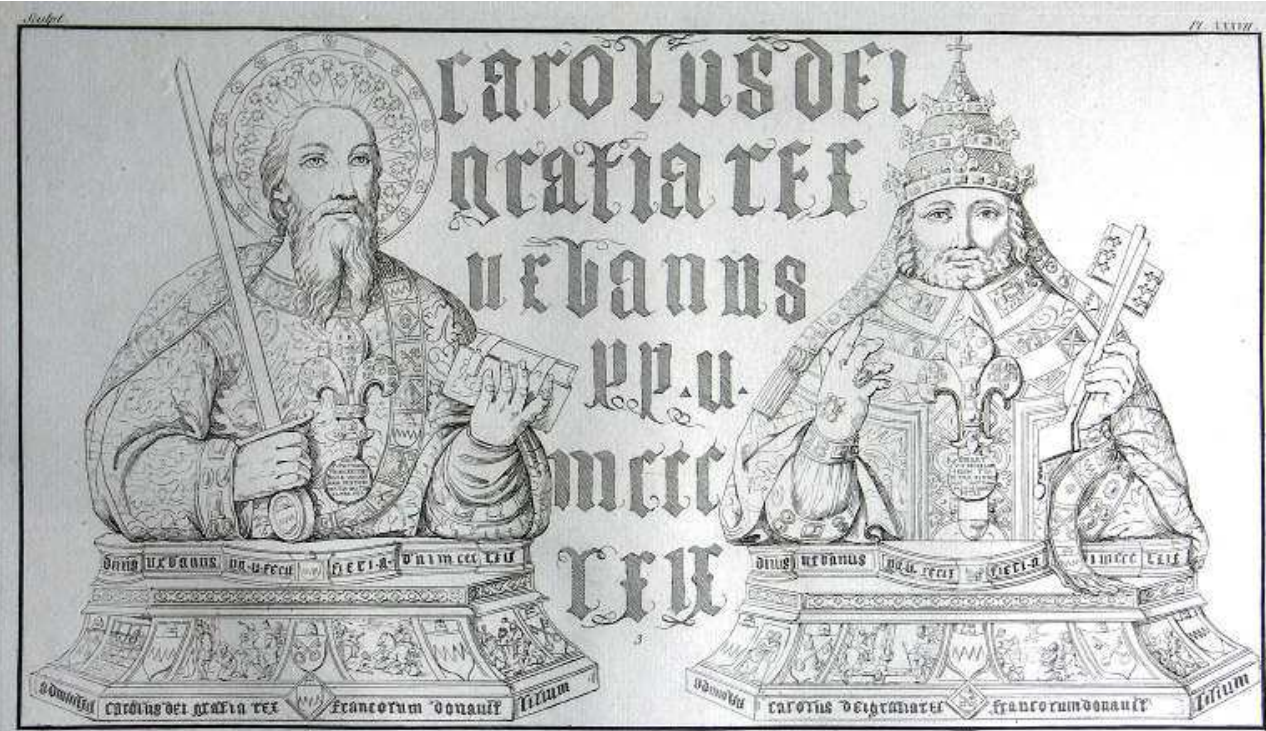

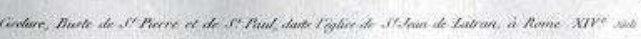

Fig. 17.3 The 'Holy Heads' of Paul and Peter, reliquaries endowed by the French pope Urban V and the French king Charles V, 1369 (Séroux d'Agincourt, Histoire de l'art par les monumens, IV, plate XXXVII (Sculpture); photo: author).

In the 1780 s - probably because they featured French insignia - the two late medieval relic receptacles were already included in the text and illustrations of the first comprehensive survey of the history of medieval art, the Histoire de l'art par les monumens by the French nobleman Jean-Baptiste Séroux d'Agincourt. ${ }^{5}$ And probably again because of the royal fleurs-de-lis appearing on them, the two silver reliquaries were confiscated from the main altar tabernacle of the Lateran at the end of November 1798, during the occupation of Rome by French troops - and were melted down for use as coins in January 1799.

This inglorious end (certainly also representing kind of a state-ordained furtum sacrilegum) and the less significant substitute reliquaries in Classicist style from the workshop of Giuseppe Valadier - which were less valuable and notably did not feature the insignia of the French crown - probably contributed to the fact that this major work of late Gothic goldsmithing art came to be forgotten.

${ }^{5}$ J. B. L. G. Séroux d'Agincourt, Histoire de l'art par les monumens depuis sa décadence au IVe siècle jusqu'à son renouvellement au XVIe, 6 vols. (Paris, 1810-23), II, 69-70, IV, pl. XXXVII (Sculpture). 


\section{From Relic to Three-Dimensional Sculpture}

But how did the 'Apostles' heads' of Peter and Paul - which might have been expected to be found in the corresponding tombs of the Apostles in San Pietro in Vaticano and San Paolo fuori le Mura on the Via Ostiense originally find their way to the Lateran? This is not known. The skull relics of Peter and Paul are first mentioned - almost in passing - in an inventory dating from the late eleventh century, as forming part of the most important relic treasury in the chapel of Saint Lawrence in the papal Lateran palace. ${ }^{6}$

Anton de Waal, Pietro Sinthern and Engelbert Kirschbaum consider that the gathering in of the 'Capita Apostolorum' to the Lateran palace took place relatively late, in the second half of the ninth century. ${ }^{7}$ Recently, Jörg Bölling has suggested that the relics of the Apostles' heads in the Lateran originated from a place of worship that had been held in traditional memory since the mid-third century, the Basilica Apostolorum on the Via Appia (today San Sebastiano). Depending on the way in which the sources are interpreted, the entire bodies of the Apostles - or only their heads, or only contact relics - were temporarily housed there in the midthird century. ${ }^{8}$ According to Bölling, the precious skull relics were thus removed before the 'sealing' of the Apostles' tombs when the basilicas were erected in the Constantinian period. ${ }^{9}$ However, the hypothesis of such an

6 Descriptio Lateranensis Ecclesiae (DLE), in R. Valentini and G. Zucchetti (eds.), Codice topografico della città di Roma, 4 vols. (Fonti per la Storia d'Italia 90) (Rome, 1940-53), III, 356-8 (quoted below in n. 12).

7 In advance of a Saracen attack, Sergius II (844-7) is said to have been warned by the duke of Tuscany, Adalbertus, that he should transfer the bodies of Peter and Paul to the city for safety; this may have taken place immediately before the plundering of the basilicas of San Pietro and San Paolo fuori le Mura by the Saracens in August 846: LP II, Life 104, 99. A. de Waal, 'Die Häupter Petri und Pauli im Lateran', Römische Quartalschrift 5 (1891), 340-8; P. Sinthern, 'Le teste dei SS. Apostoli Pietro e Paolo', Civiltà Cattolica 3 (1907), 444-57, esp. p. 456; E. Kirschbaum, Die Gräber der Apostelfürsten, 3rd edn (Frankfurt, 1974), 210-22, esp. p. 214; for a convincingly argued view that this only took place after the plundering in 846, see P. Jounel, Le culte des saints dans les basiliques du Latran et du Vatican au douzième siècle (Collection de l'École Française de Rome 26) (Rome, 1977), 102. See also Mondini, 'Reliquie incarnate', 271 n. 19.

8 During the Valerian persecutions of 258. In the sixth century the Vita of Pope Cornelius (251-3) reports that he had transferred the bodies of the Apostles from the Via Appia to their present-day location in the Vatican and to the Via Ostiense (LP I, 150; Kirschbaum, Die Gräber, 207); Gregory the Great writes that they were stolen by Orientals after the martyrdom and temporarily hidden on the Via Appia. For a summary of the positions for and against a translation to the Via Appia, see Kirschbaum, Die Gräber, 208.

9 Based on Josi's hypothesis that according to the contemporary interpretation of the law, the grave is legally located where the head is (Kirschbaum, Die Gräber, 209). J. Bölling, 'Die zwei Körper des Apostelfürsten: Der heilige Petrus im Rom des Reformpapsttums', Römische Quartalschrift für christliche Altertumskunde und Kirchengeschichte 106, 3-4 (2011), 155-92, esp. p. 161 n. 31 and pp. 178-9. Without further argumentation, Bölling places the translation to the 
early translation of such important bodily relics in Rome appears to me to be highly questionable, as it runs counter to the long-persisting ancient custom in Rome of the inviolability of tombs. ${ }^{10}$

By contrast, the fact that the translation of relics as significant as those of the most important saints of the city left no traces in the tradition, and that the relics only become tangible in their new location in sources dating from the eleventh century, raises some doubts regarding their authenticity. ${ }^{11}$ In this view, what would be involved would not be a less official translation of relics or a furtum sacrum within the city, but rather a matter of relic forgery - pious fraud.

The inventory of the relic treasury of the oratory of Saint Lawrence in the Lateran palace, compiled in 1073, clearly shows the great importance of the relics preserved there: in addition to a concentration of relics of Christ, headed by the Salvator icon, as well as the bodily relics of a large number of martyrs, the mention of four heads in a side altar - those of the Apostles Peter and Paul, along with the martyrs Agnes and Euphemia - is important. ${ }^{12}$ The impression is that an effort had been made to concentrate as much salvific power based on Roman martyrs as possible within the papal relic treasury inside the city walls.

In the context of a renovation and 'securing' of the main altar of the chapel, the relics of the Apostles' heads - and only those! - were given a facial appearance in two portrait medallions on the bronze doors of the reliquary altar endowed by Innocent III (1198-1216). It is notable that only the heads

Lateran in the tenth century, taking into consideration the origin of the skull relics in the Late Antique triclia near San Sebastiano.

10 On the triclia on the Via Appia as a site of transference of worship, rather than translation, of corporeal relics, see H. G. Thümmel, Die Memorien für Petrus und Paulus in Rom: Die archäologischen Denkmäler und die literarische Tradition (Berlin, 1999), 99.

11 I. Herklotz, 'Der mittelalterliche Fassadenportikus der Lateransbasilika und seine Mosaiken: Kunst und Propaganda am Ende des 12. Jahrhunderts in Rom', RJBH 25 (1989), 27-95, esp. p. 84.

12 'In alio vero altari eiusdem oratori sunt capita sanctorum apostolorum Petri et Pauli, et capita sanctarum Agnetis et Eufemiae virginum': Descriptio Lateranensis Ecclesiae (DLE), in its first version, written before 1073; I am quoting here from the later edition compiled by Johannes Diaconus for Pope Alexander III (1159-81): Valentini and Zucchetti (eds.), Codice topografico, III, 356-8. For a reference to the eleventh-century version of the DLE, see S. de Blaauw, 'Il patriarchio, la Basilica lateranense e la liturgia', in P. Liverani (ed.), Giornata di studio tematica dedicata al Patriarcato Lateranense: Atti della giornata tematica dei Seminari di Archeologia Cristiana (École française de Rome, 10 maggio 2001) (MEFRA 116, 1) (special issue) (Rome, 2004), 161-70, esp. p. 166. Only the authenticity of Saint Euphemia is upheld: 'capud et vestimentum sancte Agnetis, relique et vestimentum sancte Eufemie': B. Galland, Les authentiques de reliques du Sancta Sanctorum (Vatican City, 2004), 67 and authentication no. 85 . However, the authentication dates from the thirteenth century and was evidently copied when the skull relic of Saint Agnes was transferred to a new shrine under Honorius III. 


\section{CAMBRJDGE}

\section{Cambridge University Press}

978-1-108-83976-1 - The Basilica of Saint John Lateran to 1600

Edited by L. Bosman , I. P. Haynes, P. Liverani

More Information

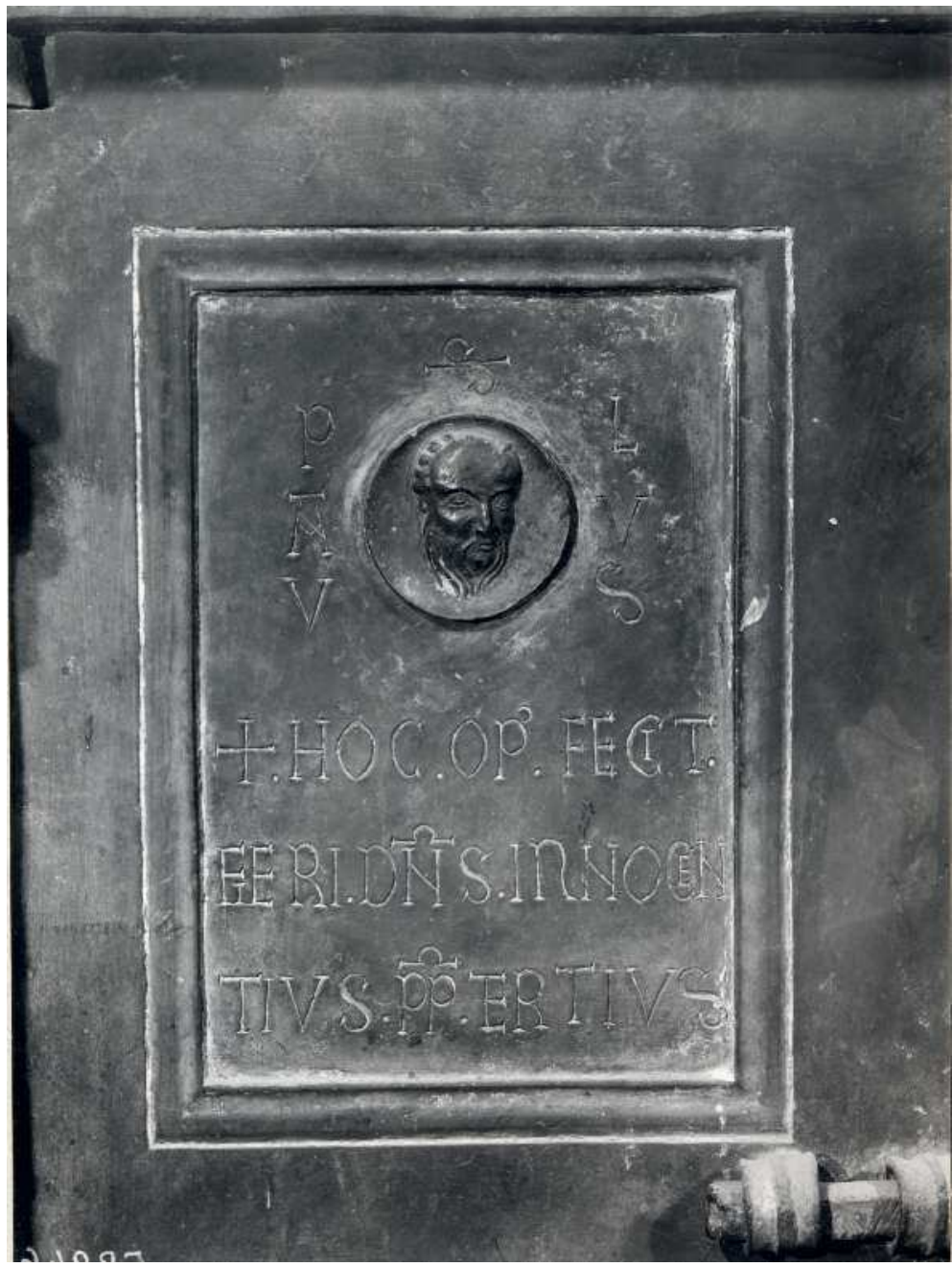

Fig. 17.4 Portrait medallion of Paul on the left bronze door of the reliquary altar endowed by Innocent III in the former chapel of Saint Lawrence in the Lateran Palace (Sancta Sanctorum) (Photo: Bibliotheca Hertziana, Rome. GFN E 59946).

are shown, without necks - probably as a direct reference to the Apostles' skulls secured behind the bronze doors in the altar (Fig. 17.4). This may have followed on from the iconography of the visualisation of the heads of Paul and Peter on papal seals that had been canonical since Paschal II (1099-1118) (Fig. 17.5). ${ }^{13}$

13 I. Herklotz, 'Zur Ikonographie der Papstsiegel im 11. und 12. Jahrhundert', in H.-R. Meier, C. Jäggi and P. Büttner (eds.), Für irdischen Ruhm und himmlischen Lohn: Stifter und Auftraggeber in der mittelalterlichen Kunst (Berlin, 1995), 116-30; Bölling, 'Die zwei Körper', 
Cambridge University Press

978-1-108-83976-1 - The Basilica of Saint John Lateran to 1600

Edited by L. Bosman, I. P. Haynes, P. Liverani

More Information



Fig. 17.5 Papal seal of Paschal II (1099-1118) with the portraits of Paul and Peter (Photo from Julius von Pflugk-Harttung, Specimina selecta chartarum Pontificum Romanorum, Pars tertia: Sigilla (Stuttgart, 1887), Tf. IX 9.7; photo @ Zentralbibliothek Zürich Aeg 423).

In the late twelfth and early thirteenth centuries the relics of the skulls of the Apostles Peter and Paul began to acquire an 'active' role in state ceremony and ritual, and they were even led in processions through the city by the pope during special political events. ${ }^{14}$ For reasons of space alone in the confinement of the reliquary altar, the so-called arca cipressina, anthropomorphic head or bust reliquaries - a rare form of reliquary that only became widespread in Rome and Latium in the late Middle Ages - are scarcely to be expected during this period. The skull relics probably rested in simple small chests of precious metal, of the type used for the heads of Saint Agnes and Saint Praxedes - two relic receptacles that belonged to the treasury of the Sancta Sanctorum. ${ }^{15}$

177; A. Paravicini Bagliani, 'Grégoire VII et l'excommunication: À propos des figures des apôtres Pierre e Paul sur les bulles pontificales', in F. Elsig (ed.), L'image en questions: Pour Jean Wirth (Geneva, 2013), 120-9.

14 For further references, see Mondini, 'Reliquie incarnate', 272-7.

15 P. Lauer, Le trésor du Sancta Sanctorum (Monuments et mémoires publiés par l'Académie des inscriptions et belles lettres 15) (Paris, 1906), 79-81 (reliquary of Saint Agnes, thirteenth century), 73-8 (reliquary of Saint Praxedes, eleventh century). 
Following the rebuilding of the chapel of Sancta Sanctorum under Nicholas III (1277-80), the pope again personally sealed the relics of the Apostles into the reliquary altar that was taken over from the previous building. Ptolemy of Lucca for the first time explicitly describes the reliquaries here as 'thecas argenteas'. ${ }^{16}$ These silver vessels had probably not been newly made and would still have been the existing simple old caskets.

The Apostles' heads in their receptacles thus vanished into the altar again along with the other reliquaries. In the chapel newly furnished by Nicholas III, however, bust portraits of Peter and Paul now appeared in the mosaic programme in the lunette above the central bay over the main altar. With their constant presence in the mosaic they represented the precious content held within the altar safe, which was closed with strong bars.

The Apostles' heads made their first truly great appearances in 1368-70, when Pope Urban V (1362-70) wished to set a clear signal on the occasion of his return from Avignon to Rome. In March 1368 the pope ordered a search for the Apostles' relics in the altar of the Sancta Sanctorum. Their rediscovery was at once celebrated with their 'spontaneous display' on the Campus Lateranensis, and the Sienese goldsmith Giovanni di Bartolo completed the new reliquaries in 1369. The official ceremonies celebrating the translation of the Apostles' heads to the Lateran church took place on Easter Monday, 16 April 1370. The new, weighty and anthropomorphic but as yet still empty! - bust reliquaries were led in procession through the city from the Vatican palace to the Lateran by three cardinals on foot (actually rather a peculiar procedure). ${ }^{17}$ In the Sancta Sanctorum the precious relics of the Apostles' skulls were transferred into the new reliquaries before the eyes of 'totius populi'. After that the reliquaries were ceremonially borne to the Lateran basilica and placed on the main altar. Here Urban V is said to have publicly stated that the alleged value of the new reliquaries was 150,000 gold florins. ${ }^{18}$ A total value of slightly over 30,000 gold florins, which is mentioned in Urban V's canonisation files, appears more realistic. ${ }^{19}$

16 Soresini, De capitibus, 83-5. Soresini quotes reports by Nicola Processi (fourteenth century) and by the Dominican Tolomeo da Lucca (1236-1326).

17 Garoscus de Ulmoisca, 'Iter italicum Urbani V Romani Pontificis' in S. Baluzius, Vitae Paparum Avenionesioum [1693], nouvelle édition d'après les manuscrits par G. Mollat, 4 vols. (Paris, 191622), IV, 136.

18 Garoscus de Ulmoisca, 'Iter italicum'; the text is quoted in Mondini, 'Reliquie incarnate', 279 n. 48.

19 'Quae secundum communem aestimationem, excedebant valorem 30. Mila florenorum de Camera': Arch. Secret. Vat. fol. 123, quoted in Soresini, De capitibus, 6 and Cancellieri, Memorie, 20 n. 1. 
The translation of the Apostles' heads represented a tremendous addition to the treasure of the episcopal church of Rome. As the ecclesiastical seat of the pope, the Lateran basilica lacked a saint's tomb, and had previously only been furnished with rather obscure relics such as the inventory of the Temple of Solomon. In comparison with Saint Peter's and other basilicas, it had previously lacked a focus of worship. In addition, the elegant reliquary tabernacle above the Magdalene altar, which was renovated in Gothic style after 1307 - just under $10 \mathrm{~m}$ away in the chapters choir - 'stole the show' from the small main altar tabernacle, which probably still dated from the early Middle Ages. ${ }^{20}$

Urban's new mise-en-scène restored the visual hierarchy among the altars within the church, and also to some extent established a balance relative to the Vatican with the tomb of Saint Peter. In addition, it initiated a type of relic display that was new in the city of Rome (Fig. 17.6). The visual expectations ${ }^{21}$ of pilgrims from north of the Alps, who were accustomed to the Gothic staging of relics, may perhaps thus have been satisfied for the first time in Rome here in the Lateran basilica. Conversely, the Apostles' heads, which had been isolated from the treasury of the Sancta Sanctorum - previously hierarchically subordinate to the relics of Christ and the icon of the Saviour not painted by human hand (acheiropoietos) rose to the status of principal relics of the highest rank. Urban V ordained an indulgence, for a visit to the Lateran basilica on the occasion of the high feast-days of Maundy Thursday, Easter, the church's consecration day, and the saints' days of Peter and Paul, on which the Apostles' heads were displayed. During the other 360 days of the year the magnificent reliquaries were hidden from pious view.

As a final measure taken to secure and increase the value of the reliquary treasure newly safeguarded in the Lateran basilica, Urban V - shortly before his return to Avignon in August 1370 - set out in a papal bull a threat of excommunication against anyone who might remove even the slightest part of the treasure. ${ }^{22}$ The document explicitly mentions 'reliquiae et imagines', since also only the precious vessels were in fact capable of arousing unwanted covetousness.

20 P. C. Claussen, Die Kirchen der Stadt Rom im Mittelalter 1050-1300, vol. 2: S. Giovanni in Laterano (Corpus Cosmatorum II, 2) (Forschungen zur Kunstgeschichte und Christlichen Archäologie 21) (Stuttgart, 2008), 198-216, figs. 115-16.

${ }^{21}$ H. R. Jauss, 'Literaturgeschichte als Provokation der Literaturwissenschaft', in R. Warning (ed.), Rezeptionsästhetik: Theorie und Praxis, 2nd edn (Munich, 1979), 126-62, at p. 127 (where he creates the concept of the horizon of expectations that is fundamental for reception aesthetics).

22 Bull of excommunication, V. Kal. Augusti 1370: Soresini, De capitibus, 47-52; Cancellieri, Memorie, 74-5. 
Cambridge University Press

978-1-108-83976-1 - The Basilica of Saint John Lateran to 1600

Edited by L. Bosman, I. P. Haynes, P. Liverani

More Information

Furtum Sacrilegum

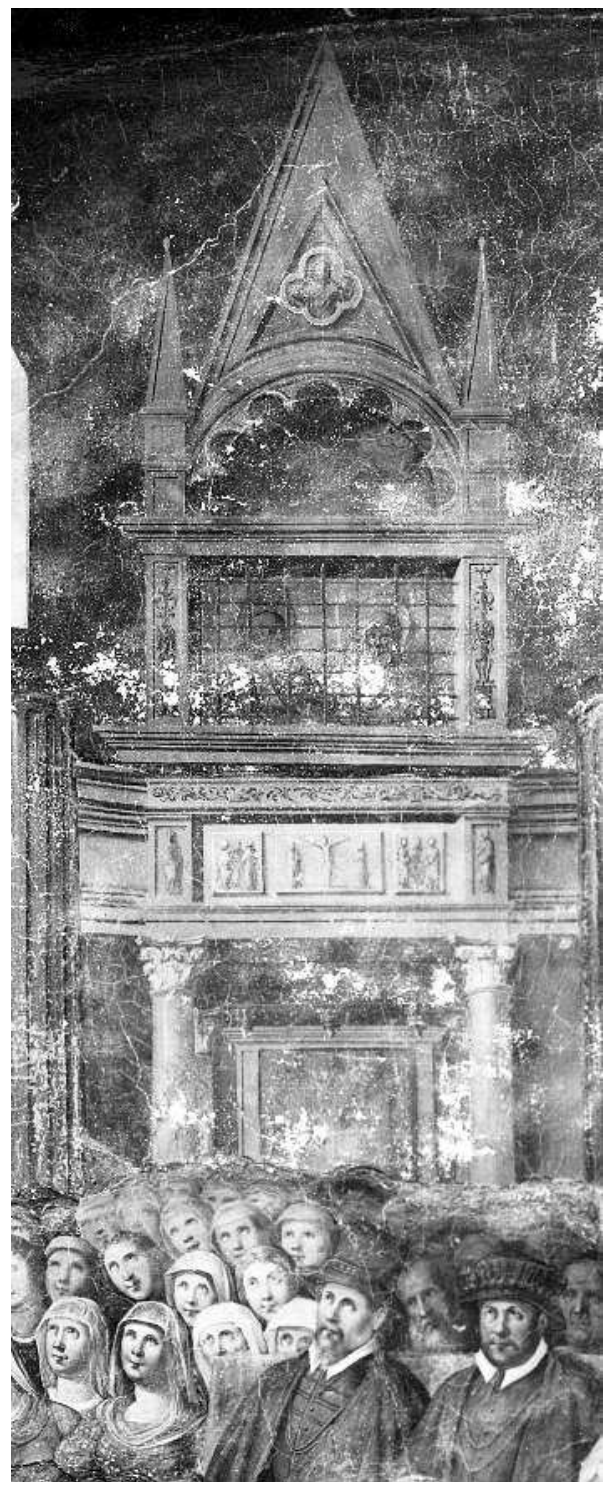

Fig. 17.6 The Lateran tabernacle during the ostention of the 'Holy Heads', detail from a fresco representing the Encounter of Saint Francis, Dominicus and the Carmelitan Saint Angelus, by Giacomo Ligozzi, c. 1600, Florence, Ognissanti, first cloister (Photo: Bibliotheca Hertziana, Rome. Pont. Comm. Arch. Sacra n. 12446).

The relics of the Apostles' heads, which first began to acquire a recognisable appearance in the chapel of Saint Lawrence in the Lateran palace before 1200, approximately at the same time as the Sudarium Christi in Saint Peter's basilica, now after a delay of some 170 years underwent the process of 


\section{CAMBRJDGE}

Cambridge University Press

978-1-108-83976-1 - The Basilica of Saint John Lateran to 1600

Edited by L. Bosman , I. P. Haynes , P. Liverani

More Information

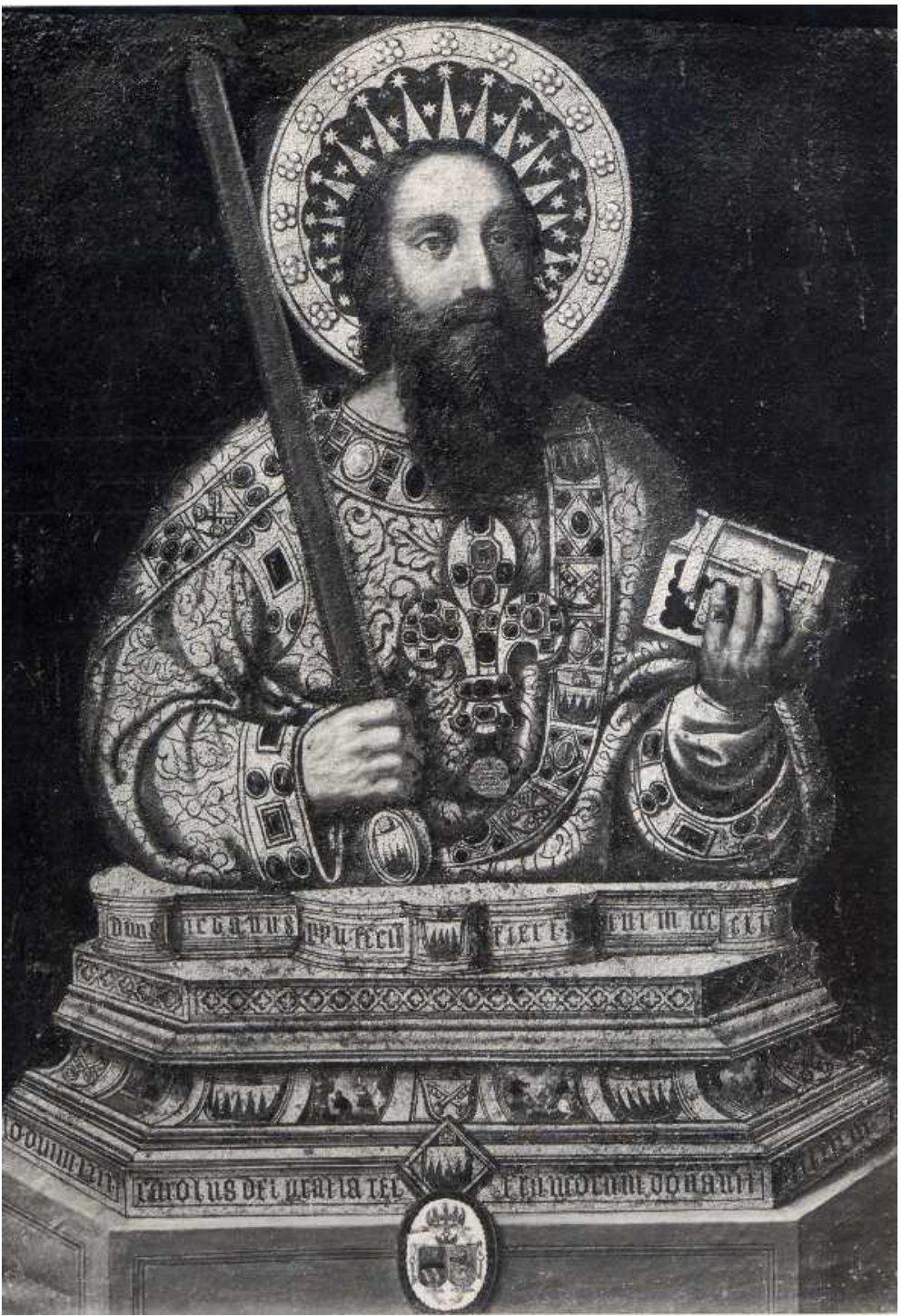

Fig. 17.7 San Giovanni in Laterano, Cappella del Coro, former Colonna chapel, late Gothic reliquary bust of Paul, painting, oil on canvas, c. 1585 (Photo: Bibliotheca Hertziana, Rome. GFN C 9028).

iconisation - from relic to image - that had previously turned Christ's sudarium (Veronica/Vera Icon) in Saint Peter's into the most popular devotional image of the late Middle Ages. The choice of the bejewelled, threedimensional medium of the bust reliquaries might perhaps be regarded as an attempt to use their physical presence to outdo the Sudarium Christi. 


\section{CAMBRJDGE}

\section{Cambridge University Press}

978-1-108-83976-1 - The Basilica of Saint John Lateran to 1600

Edited by L. Bosman , I. P. Haynes, P. Liverani

More Information

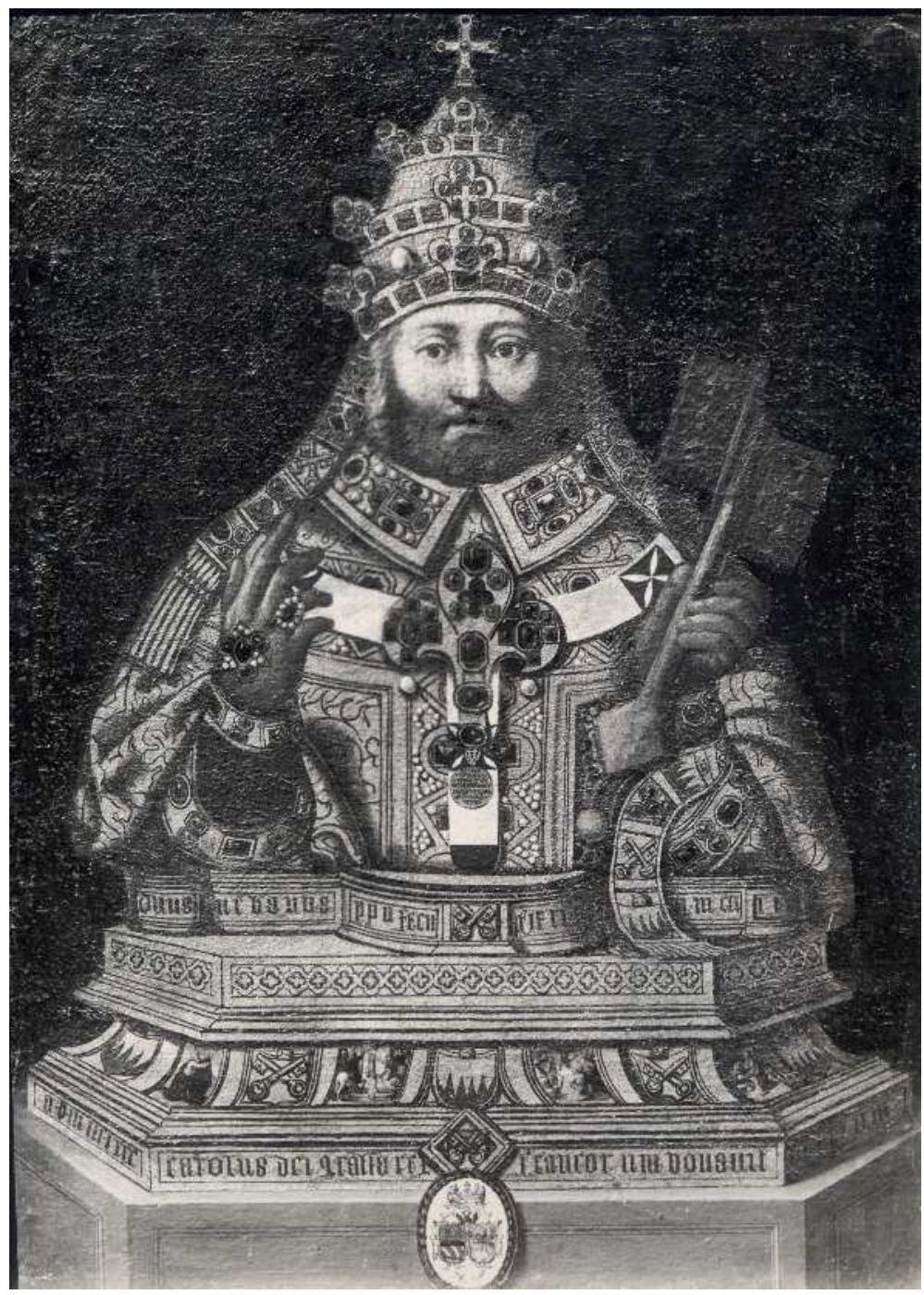

Fig. 17.8 San Giovanni in Laterano, Cappella del Coro, former Colonna chapel, late Gothic reliquary of Peter, painting, oil on canvas, c. 1585 (Photo: Bibliotheca Hertziana, Rome. GFN C 9027).

Barely a year after the death of Urban V, Gregory XI issued a bull in Avignon that raised the corresponding indulgence to the same level as that applying to the Veronica in Saint Peter's - thereby increasing the power of indulgence of the Capita Apostolorum by a factor of more than $1,000{ }^{23}$ This

23 Bull of Gregory XI (issued in Avignon, May 1371), in Cancellieri, Memorie, 76. In the last quarter of the fourteenth century the indulgence applicable to the ostension of the Veronica 
adjustment is perhaps an indication that the indulgence originally set for the newly staged apostolic relics in the Lateran did not correspond to the indulgence expectations that were customary at the time. The Apostles' heads above the high altar of the Lateran basilica had perhaps not immediately established themselves as a magnet for pilgrims, due to this 'undervaluation'.

\section{Appearance and Material Quality of the Apostolic Reliquaries}

Various pictorial and textual sources provide a fairly clear picture of the halflength jewelled silver reliquaries that were destroyed in 1799 (Figs 17.7 and 17.8). ${ }^{24}$ The two reliquaries were erected over a two-part base; their height can be estimated as a substantial $156 \mathrm{~cm}$ (seven palms). ${ }^{25}$ The base had a hexagonal ground plan, and along its fluted central zone it depicted scenes from the lives of the Apostles, alternating with the coat of arms of Urban V. In the lower border of the base, both reliquaries bore the donor inscription of the French king, Charles V, referring to the gold fleur-de-lis: 'Carolus dei gratia Rex Francorum qui coronatus fuit Anno Domini 1364 donavit praesens lilium ad honorem capitis B. Pauli, quod est in pectore eius. ${ }^{, 26}$ A second, smaller, inscription was incorporated into the band along the second, narrower part of the base, directly underneath the busts of the Apostles. This was the inscription of the principal donor, Urban V: 'Urbanus Papa V. fecit fieri hoc opus ad honorem Beati Pauli anno domini 1369. ${ }^{27}$ The signature of the goldsmith was also included beneath the figure of Saint Peter: 'HOC OPVS FECIT JOANNES BARTOLI DE SENIS AVRIFABER'. ${ }^{28}$

amounted to 3,000 years for Romans, 9,000 years for pilgrims from the vicinity and 12,000 years for travellers from afar (ultramontanis vel marinijs): Mirabilia and Indulgentiae ecclesiarum, Sankt Gallen, Stiftsbibliothek, Ms. 1093, Mondini, 'Reliquie incarnate', 283 n. 59.

24 Of particular interest are two paintings today preserved in the left choir chapel that can be dated to the pontificate of Sixtus V (1585-90) on the basis of the coats of arms (Savelli and Sixtus V) shown on their lower edges. They were probably commissioned by Cardinal Giacomo Savelli (d. 1587), who also arranged for the preservation of the bronze doors of the demolished Lateran palace. For further references, see Mondini, 'Reliquie incarnate', 284 n. 61.

25 '[S] ono d'argento smaltati d'altezza di sette palmi l'uno, e la spada che tiene in mano S. Paolo è alta cinque palmi': description by Urbano Millini, in Soresini, De capitibus, 44.

26 See also the accurate description of the reliquaries, with copies of all the surviving inscriptions, by S. Riccioni and M. Tomasi, 'Giovanni di Bartolo: Busti reliquiario dei santi Pietro e Paolo (opera perduta)', in M. M. Donato (ed.), Opere firmate nell'arte italiana/Medioevo: Siena e artisti senesi: maestri orafi (Opera Nomina Historiae 5/6, 2011-12. Repertorio) (Pisa, 2013), cat. 22.S.1, 219-24 and D'Alberto, Roma al tempo di Avignone, 150-5.

27 Description by Urbano Millini in Soresini, De capitibus, 45-6.

28 D'Alberto suggests that Johannes Bartoli's signature must also have been on the bust of Saint Paul, although it is not mentioned by Millini; she also discovered the bull of payment with the record of the goldsmith's name; a second name, Guglielmo de Frezenthis, is mentioned (ASV, 
The way in which the French king figured prominently as a fellow donor alongside the pope is of interest. Although the golden, jewel-studded fleursde-lis were explicitly mentioned as his endowment, the location of the inscription on the base and the quantity of jewels on the two busts suggest, however, that the royal endowment, which was estimated at more than 4,000 gold florins, also applied to the figures and their jewelled decoration. ${ }^{29}$ Coats of arms of the French king are also found on the ciborium. The supreme saints of Rome - Peter and Paul - are thus presented as bearing the French royal insignia. $^{30}$

The half-length figures of the Apostles had arms and torsos. Paul was bare-headed and set off with a halo; in his right hand he held the sword of his martyrdom and in his left hand a closed codex with a gold binding. Peter, whose head is framed by a heavy tiara, has a considerably stiffer appearance than his counterpart. He held the keys to Paradise in his left hand, while his right hand was raised in blessing.

The accuracy of the depiction in the two paintings is credible, as it can be verified from a slightly later description by Urbano Millini. In 1649 Millini climbed through the only door into the grating-protected high altar tabernacle for a visit and cleaning, and he made a detailed record of the sacred treasures found there under a thick layer of dust. ${ }^{31}$ Millini's meticulous inventory of the rubies, diamonds, pearls, cameos and other jewels was made for purposes of establishing their value - the rear of the reliquaries was also set with jewels (Fig. 17.9): ${ }^{32}$

A mano dritta sta la Testa di S. Paolo, tutta d'argento dorato, mezza figura del naturale con un manto, le fasce del quale sono guarnite di pretiosissime gioie; tra l'altre più cospique è sù la spalla diritta un zaffiro grosso, dov'è intagliato il Salvatore; a mano manca verso il petto una pietra bianca con

Cam. Ap. Intr. et Ex., vol. 331, fol. 114r, June 1369). It is known from archival sources that one Johannes Marci argentarius was also involved; however, the payment is related to arrangements for the transportation of the busts to the Lateran basilica: E. Müntz, 'Giovanni di Bartolo da Siena: Orafo della corte di Avignone nel XIV secolo', Archivio storico italiano, fifth series, 2 (1888), 3-20, esp. p. 8; D’Alberto, Roma al tempo di Avignone, 154-5 and n. 73.

29 Ex processu canon. Urbani V. Arch. Secret. Vat. fol. 123, Soresini, De capitibus, 6; Cancellieri, Memorie, 20 n. 1.

30 After many years' waiting, a male descendant had been born to the French king on 3 December 1368. It is possible that Charles V's endowment had a votive quality.

31 Including several gemstones that had fallen out, which were carefully collected in a small box. Report by Urbano Millini on the condition of the reliquaries in the upper storey of the ciborium, 22 December 1649, printed in Soresini, De capitibus, 33-42. Reprinted in Baldeschi and Crescimbeni, Stato della SS. chiese papale lateranense, 105-11 and Cancellieri, Memorie, 86-9.

32 Collection of drawings and graphic materials by Séroux d'Agincourt (c. 1780-90), Vatican Library (BAV), Vat. lat. 9840, fol. 72r. 
Cambridge University Press

978-1-108-83976-1 - The Basilica of Saint John Lateran to 1600

Edited by L. Bosman, I. P. Haynes, P. Liverani

More Information

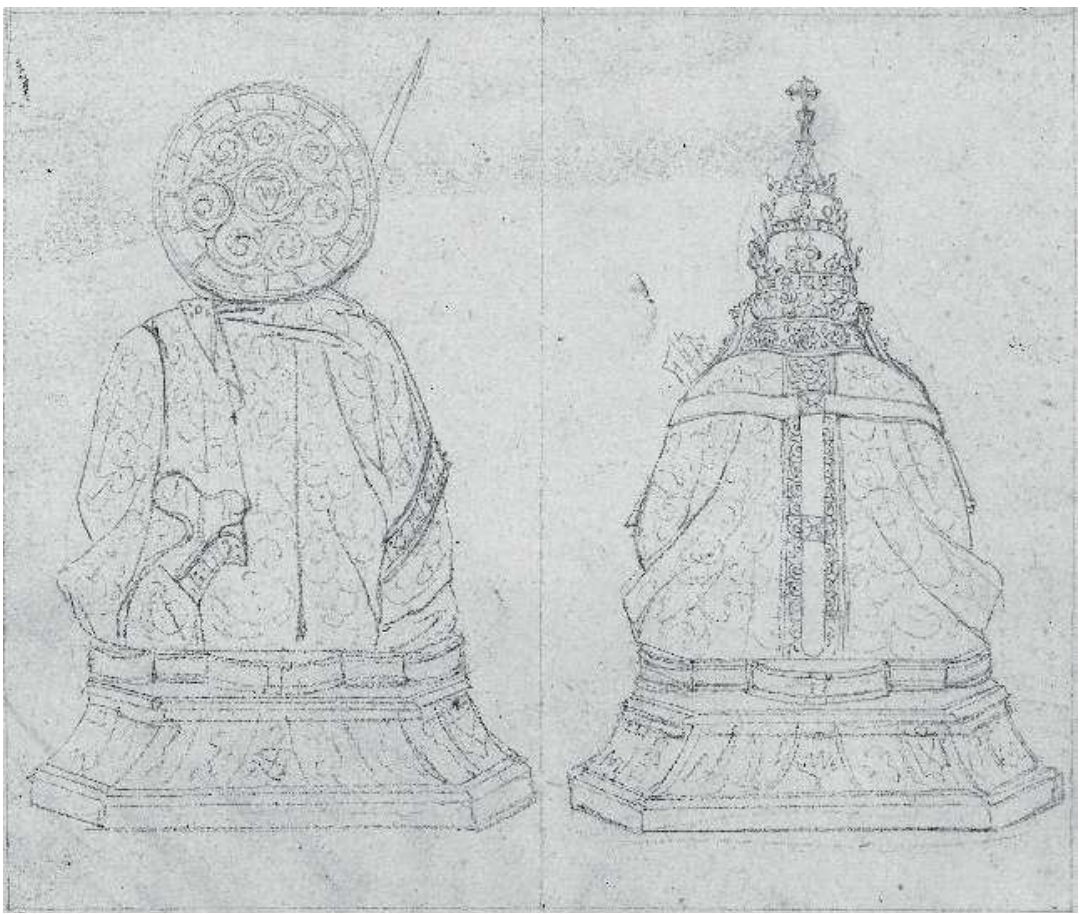

Fig. 17.9 The reliquary busts of Peter and Paul from behind (Drawing collection of Séroux d'Agincourt, Bibliotheca Apostolica Vaticana, Vat. lat. 9840, fol. 72r; (c) 2017 Bibliotheca Apostolica Vaticana).

testa naturale, dicono sia l'effigie di Nerone Imperatore, in mezzo al petto un giglio grande d'oro massiccio con tre rubini grossi, quattro balassi, e certi diamantini tramezzati, e sedici perle grosse tonde introno ... ${ }^{33}$

The written description is probably more reliable here than the reproduction in the paintings, although I think I can identify the 'pietra bianca con testa naturale' and perhaps also the sapphire with an engraved face of the Saviour in the paintings.

Counting only the 'pezzi grossi' among the jewels listed by Millini provides the following 'statistics':

- Four large sapphires and one small one

- Twelve large and five small rubies

- Seven light rubies, 'balasci' (rubino spinello, rubino balascio = rubino roseo/chiaro)

- Many small diamonds

${ }^{33}$ Description by Urbano Millini, in Soresini, De capitibus, 36; Cancellieri, Memorie, 86. 
- Thirty-seven large round pearls

- Four large emeralds (in the crucifix at the top of Saint Peter's tiara)

The two silver reliquaries were gilded. On the cloaks of the Apostles, chased work ${ }^{34}$ is used to create an impression of the raised pattern of damask material. The 'structural material', silver, only appears in its own (oxidised) material colouring in Saint Peter's two pontifical gloves and keys, as well as on the blade of Saint Paul's sword. By contrast, the two Apostles' faces and Saint Paul's hands were painted in skin colour. The naturalistic flesh tone is also attested to by Millini: 'la Testa di San Paolo oltre l'esser dorata, è la faccia, \& il collo di color di carne'. ${ }^{35}$

The flesh tone will have involved painting (with tempera on a ground of gesso or gypsum) applied to the gilded silver surface of the faces. A similar technique is found in a bust of Saint Juliana from the Cistercian convent of Santa Giuliana in Perugia, ${ }^{36}$ originating from Giovanni di Bartolo's circle after 1376, and in the more important reliquary bust of Saint Agatha in Catania (Fig. 17.10). ${ }^{37}$ The Sienese goldsmith Johannes Bartoli had returned to Avignon along with Urban V in 1370 . He made the bust reliquary for Saint Agatha of Catania based on the model of the Apostles' busts in Rome. This bust, around $80 \mathrm{~cm}$ tall without its modern base, still survives and is actively in use as an object of worship. The bust, commissioned by the bishops of Catania - Martialis and his successor Elias (depicted in translucent enamel) - in Avignon around 1373 and signed by Johannes Bartoli in 1376, can be regarded as a 'younger sister' of the Roman Apostles' reliquaries and allows some inferences to be drawn regarding their technical execution. Peter and Paul (and their sisters) are presented in their reliquaries as three-dimensional bust portraits almost of

${ }^{34}$ Séroux d'Agincourt, who was able to examine the reliquaries from close up, listed the works in his section on 'Sculpture' under the heading 'Cisélure': Séroux d'Agincourt, Histoire de l'art.

${ }^{35}$ Description by Urbano Millini, in Soresini, De capitibus, 38.

${ }^{36}$ New York, Metropolitan Museum of Art, Cloisters Collection, Inv. Nr. 61.266. The paint layer is approximately $13 \mathrm{~mm}$ thick: see R. Palm, 'Reliquienbüste der hl. Juliana von Nikomedia', in A. Legner (ed.), Die Parler und der Schöne Stil 1350-1400, 3 vols. (Cologne, 1978), I, 33.

37 In an earlier essay, I considered the possibility of the use of email à ronde bosse as a technique, in view of the quality expected in a commission for the Lateran - which would have made the two reliquaries of the Apostles the earliest examples of this elaborate method of execution (Mondini, 'Reliquie incarnate', 287). This is probably not the case: according to the recently published monograph on the bust reliquary of Saint Agatha of Catania, which is also signed by Giovanni d Bartolo and is later than the Apostle reliquaries, the flesh tone is executed in paint. However, a scientific analysis of the paint layer was not carried out; see F. Pomarici, 'Il reliquiario di Sant'Agata nel contesto della produzione artistica avignonese', in Ufficio Beni Culturali dell' Arcidiocesi di Catania, Sant'Agata il reliquiario a Busto: Contributi interdisciplinari (Catania, 2010), 23-41, esp. p. 34. 


\section{CAMBRJDGE}

\section{Cambridge University Press}

978-1-108-83976-1 - The Basilica of Saint John Lateran to 1600

Edited by L. Bosman , I. P. Haynes, P. Liverani

More Information

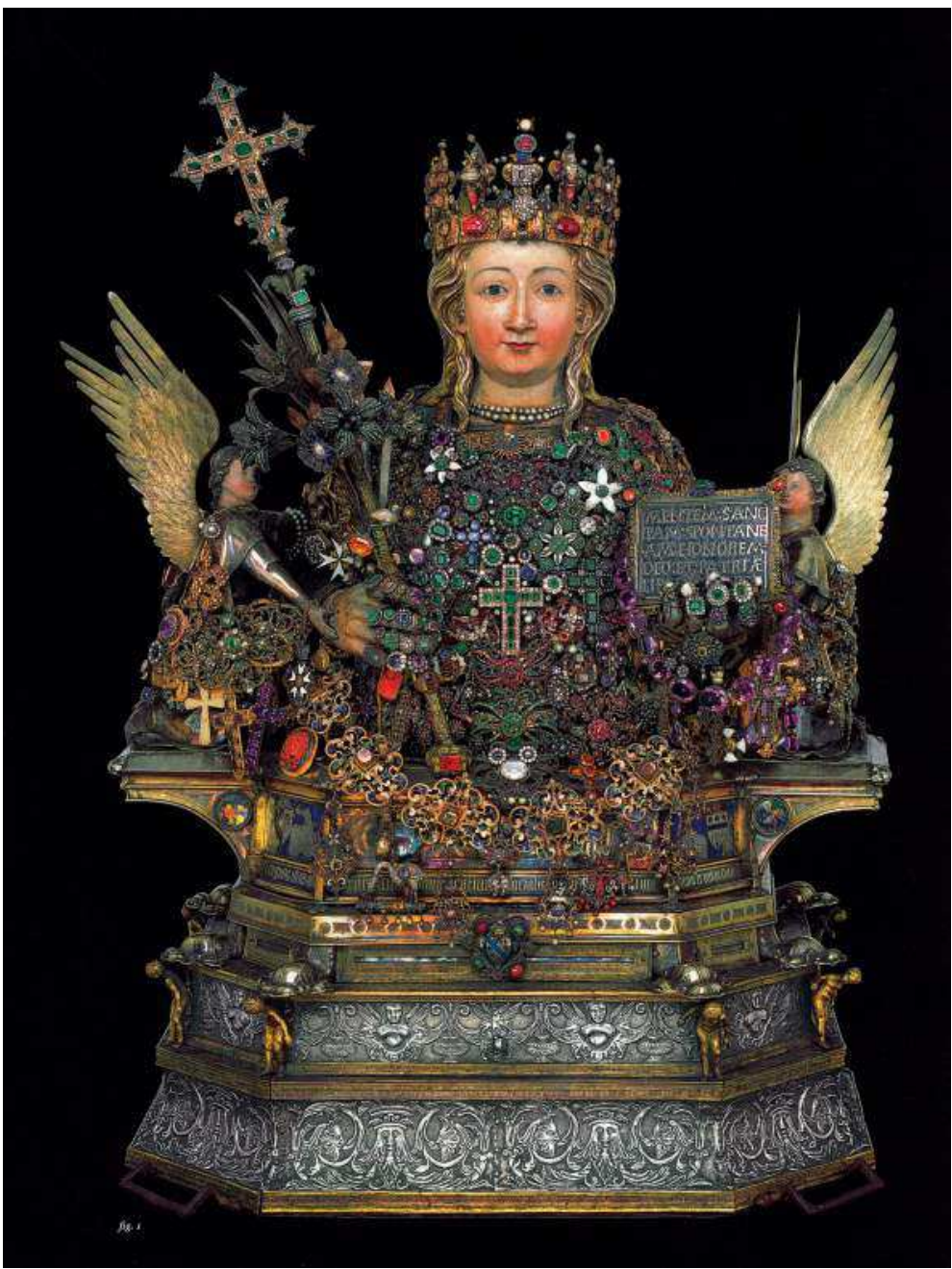

Fig. 17.10 The reliquary bust of Saint Agatha, Catania Cathedral, signed by Giovanni di Bartolo, 1376 (Photo in Sant'Agata il reliquiario a Busto, 10).

'flesh and blood', with more or less individual, amiable features. I agree with Michele Tomasi that this new trend towards the use of flesh tone in bust reliquaries may have been encouraged by the Europe-wide spread of large numbers of colourfully painted wooden busts of Saint Ursula during the fourteenth century. ${ }^{38}$ The faces were not transfigured with shining

38 The bust reliquary of Saint Ursula from Castiglione Fiorentino, dated to around 1340, might be a missing link for the spread of this type in Italy, and particularly in Tuscany: see M. Tomasi, 'L'or l'argent et la cher: Remarques sur l'usage de la couleur dans les bustes relquiaires en métal au XIVe siècle', in M. Boudel-Machuel, M. Brock and P. Charron (eds.), Aux limites de la couleur: Monochromie e polychromie dans les arts (1300-1650) (Turnhout, 2011), 133-44, esp. p. 139. 
gold. The saint in the bust reliquary is no longer shown in the celestial radiance of the shining body he was then thought to have in the afterlife, but instead almost 'reincarnated' as a human, in an image commemorating his earthly, corporeal existence. ${ }^{39}$ On the day before Easter 1581, Michel de Montaigne recorded the vivid effect of the two busts and ostension practices in his Journal du voyage:

On Easter eve, I saw at Saint John Lateran the heads of Saint Paul and Saint Peter, which have still some flesh upon them, and are coloured and bearded as in life. The face of Saint Peter is fair, somewhat elongated, with a ruddy, almost sanguine tint on the cheeks, and a forked grey beard, the head being covered with a papal mitre. That of Saint Paul is dark, broad, and fatter; the head altogether being larger and beard thick and grey. They are kept high up in a place devised for them, and the exhibition is made in this wise. The people are summoned by the ringing of bells, then a curtain, stretched before the heads, is let down, and they may be seen side by side. They are left visible long enough to let the spectators say an Ave Maria, and then the curtain is drawn up again. Afterwards they are displayed afresh in the same way, and then for a third time. This exhibition takes place three or four times during the day. The place where they are kept is about the height of a pike from the ground, and a heavy iron grating is in front of them, through which the spectator must peer in order to see them, several candles being lighted outside the grating, but it is difficult to discern clearly the particular features. I saw them three or four times, and found the skin shiny and something like the masks we use. ${ }^{40}$

During ceremonial reliquary displays the ciborium was equipped with a balcony-like stage (Fig. 17.11). ${ }^{41}$ Members of the higher nobility were

39 Mondini, 'Reliquie incarnate', 289.

40 'La veille de Pasques, je vis à S. Jean de Latran, les Chefs S. Pol \& S. Pierre qu'on y montre, qui ont encore leur charnure, teint \& barbe, come s'ils vivoint : S. Pierre, un visage blanc un peu longuet, le teint vermeil \& tirant sur le sanguin, une barbe grise fourchue, la teste couverte d'une mitre papale ; \& S. Pol, noir, le visage large \& plus gras, la teste plus grosse, la barbe grise, espesse. Ils sont en haut dans un lieu exprès. La façon de les montrer, c'est qu'on apele le peuple au son des cloches, \& que à secousses, on devale contre bas un rideau au derriere duquel sont ces testes, à costé l'une de l'autre. On les laisse voir le tamps de dire un Ave Maria, \& soudein on remonte ce rideau : après on le ravale de mesmes, \& cela jusques à trois fois : on refaict cete montre quatre ou cinq fois le jour. Le lieu est élevé, de la hautur d'une pique, \& puis de grosses grilles de fer, au travers lesqueles on voit. On alume autour par le dehors, plusieurs sierges ; mais est mal aisé de discerner bien cleremant toutes les particularités ; je les vis à deus ou trois fois. La polissure de ces faces avoit quelque rassemblance à nos masques': A. d'Ancona (ed.), Journal du voyage de Michel Montaigne en Italie par la Suisse et l'Allemagne en 1580 et 1561 (Città di Castello, 1889), 312, trans. in W. G. Waters, The Journal of Montaigne's Travels in Italy, 3 vols. (London, 1903), II, 156-8. I am grateful to Ingo Herklotz for this reference.

41 BAV, Vat. lat. 5479, fol. 12r-v (Visitatio Clementis VIII anno 1592), before the redecoration of the transept: 'Deinde ad principum Apostolorum capita inspicienda et veneranda Clemens accessit, ascendit Pontifex sequentibus illum Cardinalibus quinque, qui aderant, Archiepiscopo, et Episcopo, 


\section{CAMBRJDGE}

\section{Cambridge University Press}

978-1-108-83976-1 - The Basilica of Saint John Lateran to 1600

Edited by L. Bosman , I. P. Haynes , P. Liverani

More Information

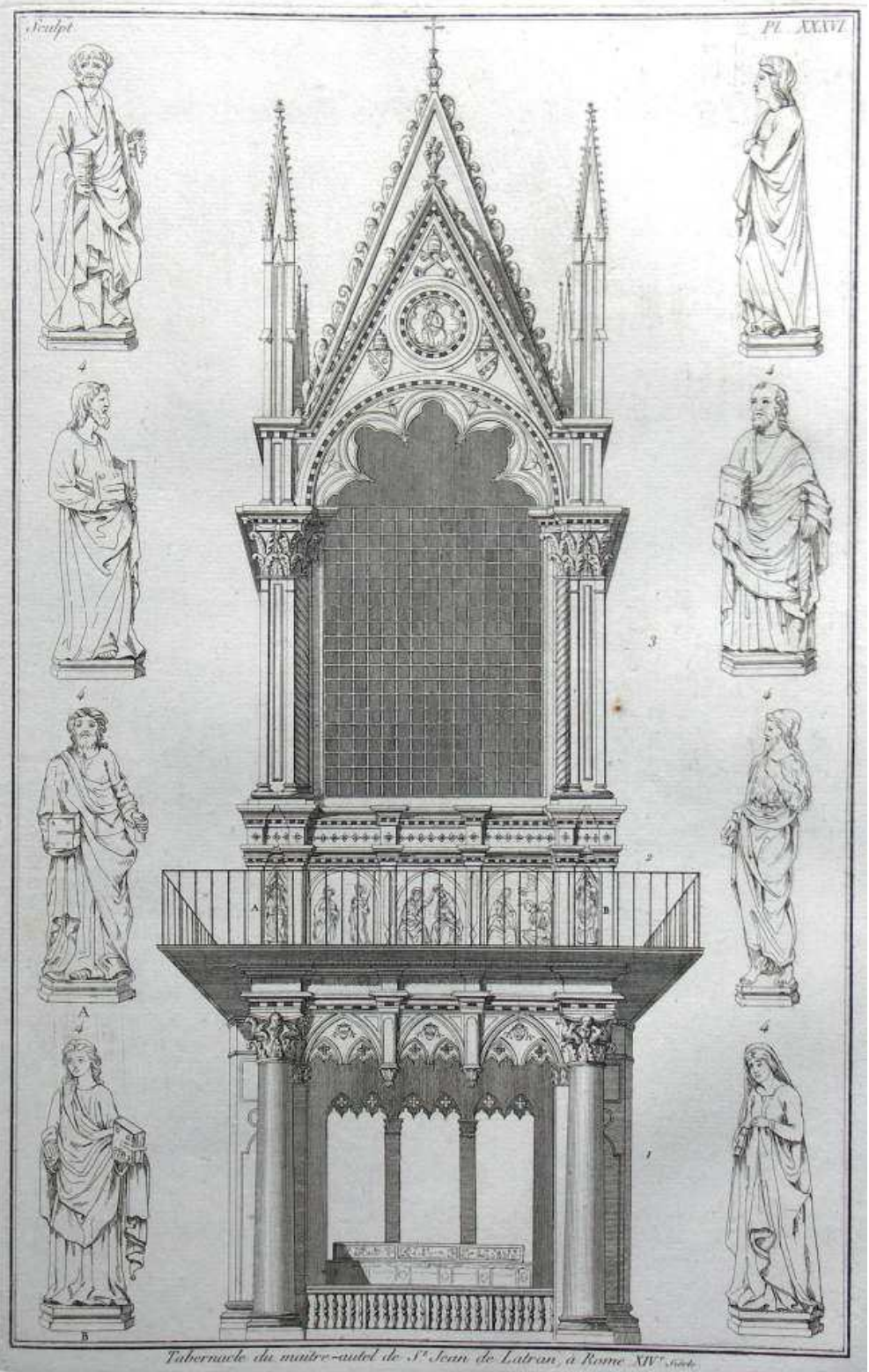

Fig. 17.11 The Lateran tabernacle with a balcony-like stage (western side) (Séroux d'Agincourt, Histoire de l'art, IV, plate XXXVI (sculpture)).

et perpaucis aliis, per ligneum pontem, qui extructus fuerat ut commode in locum illum conscend posset, ubi Thesaurus ille pretiosissimus ecclesiae, capita sanctorum Petri et Pauli asservantur, (...). Vidit Pontifex in sacro angusto illo loco, et veneratus est, viderunt et venerati sunt genuflexi cum Pontifice Cardinales principum Petri et Pauli sanctissima capita, quae Vrbanus quintus Pontifex, eximia pietate uir, smaragdis, sapphiris, unionibus, et quamplurimis aliis gemmis pretiosissimis ornanda curavit' (information kindly provided by Darko Senekovic). 
permitted to ascend and view the reliquaries from close up. Even ordinary people were allowed at least once, in 1438 , to ascend the podium to witness that all of the jewels had been returned to their places following a sacrilegious theft.

\section{Furtum Sacrilegum: A Fresco Cycle of Horror and Deterrence}

In order to deter future generations, the archpriest of the Lateran basilica, Cardinal Angelotto Foschi (d. 1444), had the theft recorded in a fresco sequence on the west wall of the north transept between 1438 and 1440 , along with details of the subsequent show trial and public execution. ${ }^{42}$ (Angelotto's endowment of it also included a host miracle altar erected there, which probably incorporated an earlier fresco showing Maria Advocata). ${ }^{43}$ Nothing is known about the artists involved in executing the fresco; they may have been associated with the workshops of Gentile da Fabriano and his successor Pisanello, who left the paintings in the nave of the basilica incomplete under Eugenius IV. ${ }^{44}$ Drawings copying the fresco cycle of the historical event - described by Arnold Nesselrath as the earliest known example of a cycle of images depicting events - have survived. ${ }^{45}$ Published in full for the first time by Rossella Magrì in 1988, they were lost in the Lateran archives for a long period and have only recently reappeared. ${ }^{46}$ The copies also document three scenes from an older cycle recording a theft committed

42 'Postremus in portico est maximus paries ... (= apse side) paries ipse variis picturis est ornatus et eorum supplicis qui furto quaedam ex hac Basilica asportarunt': Panvinio, after P. Lauer, Le palais du Latran: Étude historique et archéologique (Paris, 1911), 435; Claussen, Die Kirchen der Stadt Rom, 146.

43 The altar is now located in the chapel of Saint John the Evangelist in the Lateran baptistery, and the overpainted fresco fragment dating from the late thirteenth century is in the cloister; on this point, see D. Senekovic, 'S. Giovanni in Fonte und S. Croce in Laterano', in Claussen, Die Kirchen der Stadt Rom, 355-93, at pp. 375-7 and G. Bordi and F. Consoli, 'S. Giovanni in Laterano', in M. Andaloro (ed.), La pittura medievale a Roma 312-1431: Atlante percorsi visivi, vol. I: Suburbio, Vaticano, Rione Monti (Milan, 2006), 193-202, esp. p. 195, fig. at p. 201 (where the Cappella del Santi Sacramento in the Scala Santa building is incorrectly given as the provenance).

44 A. De Marchi, 'Gentile da Fabriano et Pisanello à Saint-Jean de Latran', in Dominique Cordellier and Bernardette Py (eds.), Pisanello: Actes du colloque organisé au musée du Louvre 26-28 juin 1996 (La documentation française I) (Paris, 1998), 161-213; See also De Marchi, Chapter 18 in this volume.

45 A. Nesselrath, 'Bildgeschichte - Geschichtsbilder', in M. Matheus, B. Schneidmüller, S. Weinfurter and A. Wieczorek (eds.), Die Päpste der Renaissance: Politik, Kunst und Musik (Regensburg, 2017), 49-67.

46 Archivio Capitolare Lateranense, Q.8.D.1.; pen on paper, 50 x $235 \mathrm{~cm}$; the sequence of the scenes was confused when the sheets were mounted on card. Basic details in R. Magrí, 'La lupa simbolo di giustizia in Laterano', in A. Nesselrath (ed.), Da Pisanello alla nascita dei Musei Capitolini: L'Antico a Roma alla vigilia del Rinascimento (exhibition catalogue) (Milan, 1988), 225-6 (cat. no. 71). 
by Andreuccio da Peroscia ${ }^{47}$ in 1364 (probably of church property, possibly from the treasury of the Sancta Sanctorum) and his execution by hanging (Figs 17.12, 17.13 and 17.14). ${ }^{48}$ It is not clear from the late sixteenth-century copies whether the scenes depicting the theft and the punishment of Andreuccio de Peroscia, who was executed in 1364, date from an earlier period or whether they were also commissioned by Angelotto Foschi so that the updating would doubly maintain awareness of the just and cruel punishments meted out for a furtum sacrilegum. It appears probable, however, that they do in fact date from the trecento and may even have served as a model for the later cycle - since the name of Ciuccio Jani Catini, a highly influential representative of the 'popolo grasso' ahead of the schism of 1378 (Fig. 17.15), appears below the coat of arms shown on the last sheet (lower row) and tituli. $^{49}$ In addition, the space in the scene showing the torture of Andreuccio is indicated in inverse perspective, while in the other cycle perspective lines aligned towards the rear can be seen. It is not possible to discuss that cycle in greater depth here; that will require a separate study. ${ }^{50}$

To return to the events of 1438: according to contemporary reports by Stefano Infessura, as well as Paolo di Liello Petrone and Paolo de lo Mastro, the offenders on the night of Easter Monday, 12 April 1438 were insiders. ${ }^{51}$

47 Perhaps not coincidental, in my view, is the fact that the name is the same as that of the protagonist of the fifth story of the second day in Boccaccio's Decameron (c. 1350). As is well known, Boccaccio certainly made use of contemporary events and characters in the novellas of the Decameron. The simple horse-dealer Andreuccio da Perugia gets caught up in various criminal intrigues in the story. With a bit of luck and innocent cunning, the sympathetic rogue even succeeds in seizing with impunity a ruby worth 500 gold florins from the tomb of the archbishop of Naples, who might be identified with Orso Minutolo (d. 1333) and buried in the Minutolo family chapel (N. Bock, 'I re, i vescovi e la cattedrale: Sepolture e costruzione architettonica', in S. Romano and N. Bock (eds.), Il Duomo di Napoli dal paleocristiano all'età angioina (Naples, 2002), 132-47, at p. 139. In view of the incomplete state of the sources for Rome during the trecento, this lost fresco perhaps represents the only documentary trace of Andreuccio's inglorious end. One might wonder whether an educated contemporary viewer of the frescos might have recalled Boccaccio's hero when gazing at the hanged Andreuccio; but the link was not made in the antiquarian literature.

48 Magrí, 'La lupa', 225. The first sheet of the rotulus transcribes the tituli and inscriptions for the figures and coats of arms: 'lettere sotto le arme. Hoc fuit sub anno dni M.CCC. LXIIII. in mense Magio / (quello che si tenaglia) Andreuccio da Peroscia /(impiccato si chiama) Andreuccio da Peroscia.'

49 Magrí, 'La lupa', 225. I am grateful to Andreas Rehberg for valuable information here. On Ciuccio Jani Catini, see A. Rehberg, 'Il Rione Trastevere e i suoi abitanti nelle testimonianze raccolte sugli inizi dello Scisma del 1378', in L. Ermini Pani and C. Travaglini (eds.), Trastevere: Un'analisi di lungo periodo (Convegno di Studi 2008) (Rome, 2010), 255-317, esp. pp. 283-5.

50 A more detailed study and heraldic analysis of the rotulus and the historical events documented on it is currently in preparation in collaboration with Andreas Rehberg.

51 Transcripts in Cancellieri, Memorie, 77-80, and R. Magrí, 'La mesticanza', in Nesselrath (ed.), Da Pisanello, 227-8; S. Infessura, Diario della città di Roma di Stefano Infessura scriba senato, ed. O. Tommasini (Fonti per la storia d'Italia 5) (Rome, 1890) 36-8. 


\section{CAMBRIDGE}

\section{Cambridge University Press}

978-1-108-83976-1 - The Basilica of Saint John Lateran to 1600

Edited by L. Bosman , I. P. Haynes, P. Liverani

More Information

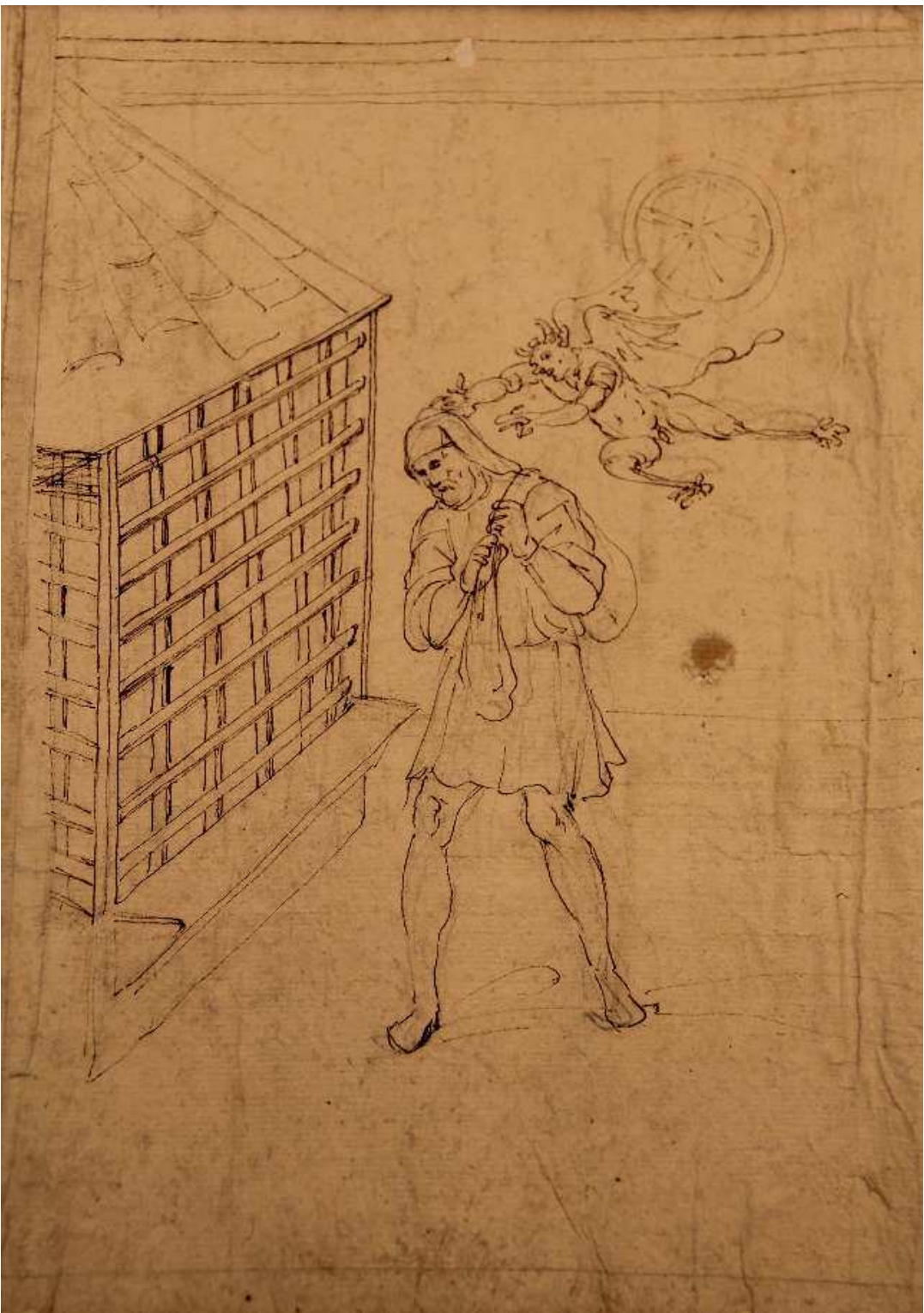

Fig. 17.12 Andreuccio da Peroscia (?) stealing ecclesiastical goods (?); copy of a lost fresco cycle, dated 1364, formerly in the north transept of the Lateran basilica, roll of pen drawings (end of the sixteenth century) (Archivio Capitolare Lateranense).

Domenico de Tito Capocciola and Cristoforo Garofalo were beneficiates of the Lateran, and may have held the office of supervisor of the Apostles' 
Cambridge University Press

978-1-108-83976-1 - The Basilica of Saint John Lateran to 1600

Edited by L. Bosman , I. P. Haynes , P. Liverani

More Information



Fig. 17.13 Andreuccio da Peroscia being punished with incandescent irons; copy of a lost fresco cycle, dated 1364, formerly in the north transept of the Lateran basilica, roll of pen drawings (end of the sixteenth century) (Archivio Capitolare Lateranense).

relics; ${ }^{52}$ their uncle, the Lateran canon Nicola di Valmontone, aided and abetted them. ${ }^{53}$ They acted a second time in June, on the feast day of Saints Peter and Paul. On each occasion it was thus a day on which the 'sacre teste' were ceremonially displayed and the stage of the ciborium was accessible by

52 The regulation regarding the way in which the 'Custodes Beneficiati, pro Custodia Capitum Beatorum Apsotolorum' were to be selected by the Chapter of the Lateran was already included in the Constitutiones Lateranensis Ecclesiae under Urban V in 1370: see Cancellieri, Memorie, doc. XII, 76-7.

53 Soresini, De capitibus, pp. 53-4, gives the full names and origins of the perpetrators from an accounts book in the Lateran Archive that can no longer be located at the shelfmark he gives ('liber introit. \& exit. Lateran. Eccles. Sign. Litt. E. fol 150'): 'Dominicus de Tito Capocciola Apulus et Iohannes Christophorus Garophalus Castri Vallis montanae'. However, the subsequent mention of 'Nicolaus Andreuccio de Peroscia ex eodem Castro', is incorrect, since this combines the names of two different people - Nicolaus de eodem Castro (= Valmontone) and Andreuccio de Peroscia. The inscription on the rotulus gives the former titulus of the fresco in Italian: 'Lettere sotto l'historia suddetta sono queste. Come Domenico de Tito de Puglia, et Janni Garofalo di Valle Montone furaro le prete preziose de Santo Pietro et Paolo'. Archivio Capitolare Lateranense, Q.8.D.1: Magrì, 'La lupa', 225. There is no surviving titulus which would identify the figure of the Lateran canon Nicolaus de Valmontone on the paintings. 


\section{CAMBRIDGE}

\section{Cambridge University Press}

978-1-108-83976-1 - The Basilica of Saint John Lateran to 1600

Edited by L. Bosman , I. P. Haynes , P. Liverani

More Information

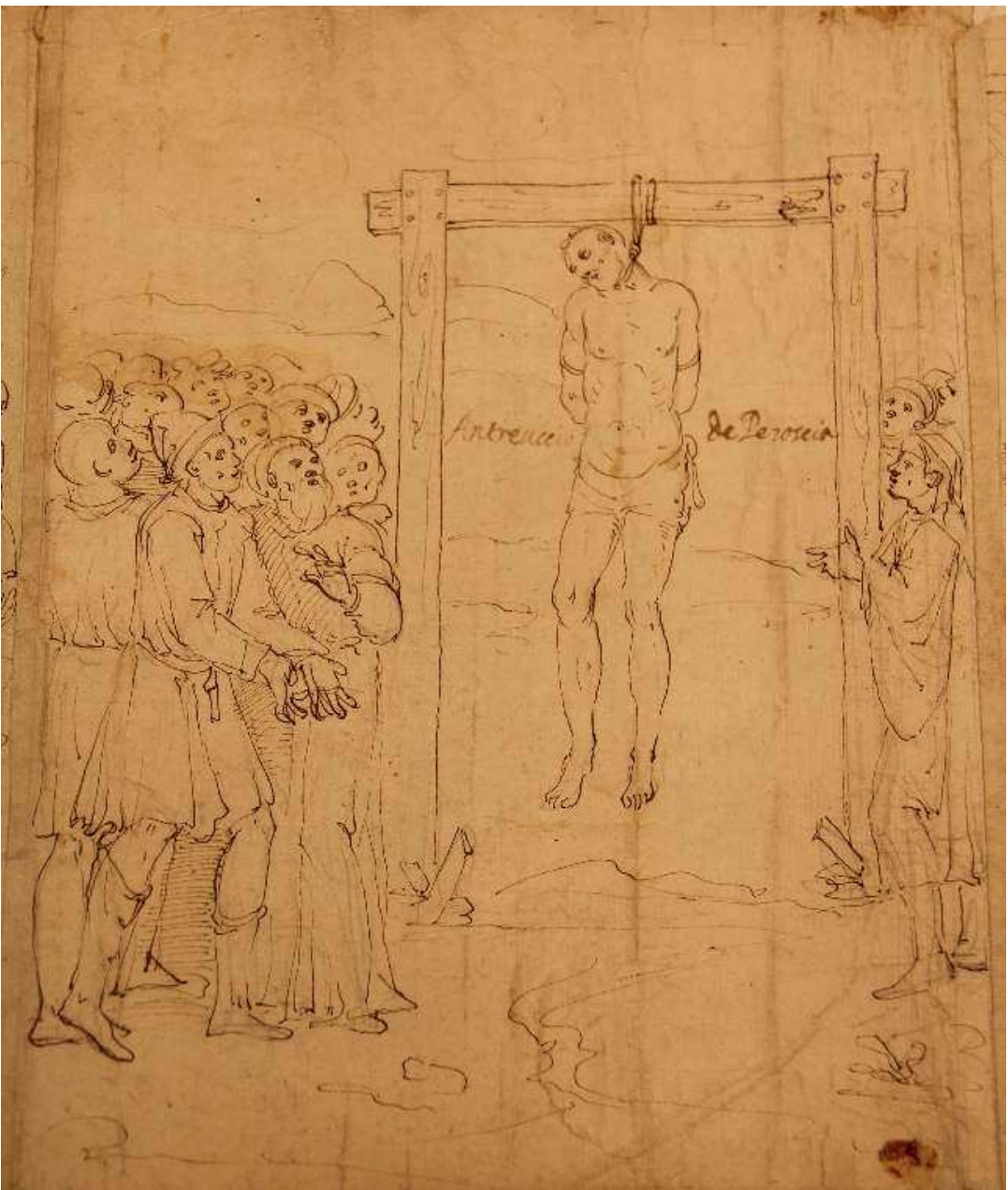

Fig. 17.14 Execution of Andreuccio da Peroscia; copy of a fresco cycle, dated 1364, formerly in the north transept of the Lateran basilica, roll of pen drawings (end of the sixteenth century) (Archivio Capitolare Lateranense).

ladder. The first scene shows only the upper storey of the Lateran tabernacle, in a kind of 'close-up' (Fig. 17.16). Three moments from the deed are recorded simultaneously: we see the two thieves in the interior of the 'gabbia' of the tabernacle in the act of 'plucking' the jewels - 'molte petre preziose, zafiri, balassi, ametisti et perle ${ }^{, 54}$ - from the reliquaries; then their

${ }^{54}$ Infessura, Diario, 37; Cancellieri, Memorie, 77. The chronicler Paolo de Lello Petrone discusses the value of the booty in detail: '.. la notte cavaro dalla mitra che tiene S. Pietro in capo, dui finissimi balasci, un finissimo zaffiro, tre finissimi diamanti, 12 perle grosse, li quali balasci, di poi che vennero alle mano del regimento uno però 48 carati e l'altro 47 et vale la carata 28 ducati 
Cambridge University Press

978-1-108-83976-1 - The Basilica of Saint John Lateran to 1600

Edited by L. Bosman , I. P. Haynes , P. Liverani

More Information



Fig. 17.15 Coat of arms belonging to the lost fresco cycles in the north transept of the Lateran basilica, roll of pen drawings (end of the sixteenth century) (Archivio Capitolare Lateranense).

flight through the arch opening above the protective bars (the fresco thus also reveals the gap that existed in the 'security arrangements' of the Lateran ciborium). On the right edge of the picture, finally, it is probably their accomplice the Lateran canon Nicola di Valmontone who is shown making contacts for reselling the booty.

According to Infessura, the whole affair came to light because a certain Servestro de Pallone, who had purchased a large pearl for 30 ducats, had a disagreement with his goldsmith that had to be settled publicly. In the process, the trail led back to the pearl's seller, the canon Nicola di Valmontone, and suspicions were aroused. The two thieves were caught near Velletri; all of the jewels were returned to the Lateran on 22 August 'con tutta la processione di Roma e giro lo Senatore di Roma con tutti li Offitiali con tutto lo popolo, et lo

et più hera stimato quanto valevano li balasci, quanto potevano valere li diamanti, il zaffiro et le perle, et non contenti li ribaldi di questo il dì di S. Pietro e S. Paolo il Giugno seguente ne tolsero 18 altre pietre finissime d'infinita valuta, et queste cose furono ritrovate et reposte nelli lochi dove furon tratte ... ': Paolo di Lello, cited after Magrí, 'La mesticanza', 227. 


\section{CAMBRJDGE}

\section{Cambridge University Press}

978-1-108-83976-1 - The Basilica of Saint John Lateran to 1600

Edited by L. Bosman , I. P. Haynes , P. Liverani

More Information



Fig. 17.16 Cappocciola and Garofalo stealing the jewels from the reliquary busts of Peter and Paul in the tabernacle of the Lateran; copy of a fresco cycle (1438-40), formerly in the north transept of the Lateran basilica, roll of pen drawings (end of the sixteenth century) (Archivio Capitolare Lateranense).

Senatore lesse la scommunica che fece papa Urbano V, lo quale pose lì quelle teste e ornolle colle ditte prete..$^{55}$

${ }^{55}$ Infessura, Diario, 37. 
The coat of arms of the Roman senator who was in office at the time, Francesco de Salimbeni, ${ }^{56}$ appears in the upper row of coats of arms, which was probably depicted underneath the cycle. At the sides of the coat of arms of Pope Eugenius IV, the arms of Papal condottiere and cardinal Giovanni Maria Vitelleschi (d. 1440) and of the archpriest of the Lateran basilica, Angelotto Foschi, who commissioned the paintings, are also recognizable (Fig. 17.15). ${ }^{57}$

According to a different version of the events recorded by Soresini, it was by contrast the Holy Spirit who provided active assistance in tracing the stolen goods. ${ }^{58}$ A Venetian nobleman who was dangerously ill had wanted to offer an extremely valuable pearl, which he had unwittingly purchased from the thieves, to Saints Peter and Paul as a gift, in order to obtain a cure. When the delighted clerics in the Lateran climbed up to the ciborium to add the pearl to the Apostles' reliquaries, it was discovered 'that the ruby, the sapphire, the diamonds, pearls and other jewels were missing, but what caused the greatest astonishment was that both the size and shape of the donated pearl and also a certain empty space there left no doubt that the pearl had previously been set there'. The Romans were able to obtain the name of the seller from the Venetian, who had in the meantime been cured, as well as the time and circumstances of the sale, and they succeeded in convicting the perpetrators.

The deed was regarded as sacrilege (theft of a consecrated object from a consecrated space), ${ }^{59}$ and its brutal consequences for the convicted thieves are displayed in the following scenes, documented in the rotulus. One scene is

56 C. De Dominicis, Membri del Senato della Roma pontificia: Senatori, conservatori, caporioni e loro priori e lista d'oro delle famiglie dirigenti (sec. X-XIX) (Rome, 2009), 171.

57 Final sheet of the rotulus; the coats of arms were probably placed as a frieze underneath or above the cycle of frescos.

58 Soresini, De capitibus, 56-8, gives as his source the custodian of the Vatican Library, Leo Allatius (Leone Allacci), who claimed to have read this report in an old codex - not further specified.

59 G. Dahm, Das Strafrecht Italiens im ausgehenden Mittelalter: Untersuchung über die Beziehung von Theorie und Praxis im Strafrecht des Spätmittelalters, namentlich im 14. Jahrhundert (Beiträge zur Geschichte der deutschen Strafrechtspflege 3) (Berlin, 1931), 476. Urban's bull of excommunication, which was intended to protect the relics and their reliquaries, begins with the words 'Sacrilegorum damnanda praesumptio' (see above, n. 22). For an explanation of this in canon law, see A. Reiffenstuel (OFM), Jus canonicum universum (n. p., 1717), titulus 18 (De furtis), nos. $54-5,234-5$. One of the earliest mentions of the concept of furtum sacrilegum is found in the autobiography of Guibert de Nogeant in the twelfth century: Guibert de Nogent, Vie de Guibert de Nogent, par lui-même, book III (XII to XXI), chap. XV (XVI): 'Secundo quidam Ansellus vulgo urbis oriundus, immanis et rusticus, infra dies Dominici natalis ante matutinos, cruces, calices, aurea quaeque subripuit. Cumque post aliquod tempus praerepti auri massulam Suessonico cuidam mercatori venum tulisset, et furtum sacrilegum quod fecerat, prodidisset, ac sacramentum ab eo ne se proderet accepisset, ille interim damni illius conscios per Suessorum parochias excommunicari audivit.' E.-R. Labande (ed. and trans.), Guibert de Nogent, Autographie (Les classiques de l'histoire de France au moyen âge 34) (Paris, 1981), book III, chap. XV, 418. 


\section{CAMBRIDGE}

\section{Cambridge University Press}

978-1-108-83976-1 - The Basilica of Saint John Lateran to 1600

Edited by L. Bosman , I. P. Haynes, P. Liverani

More Information

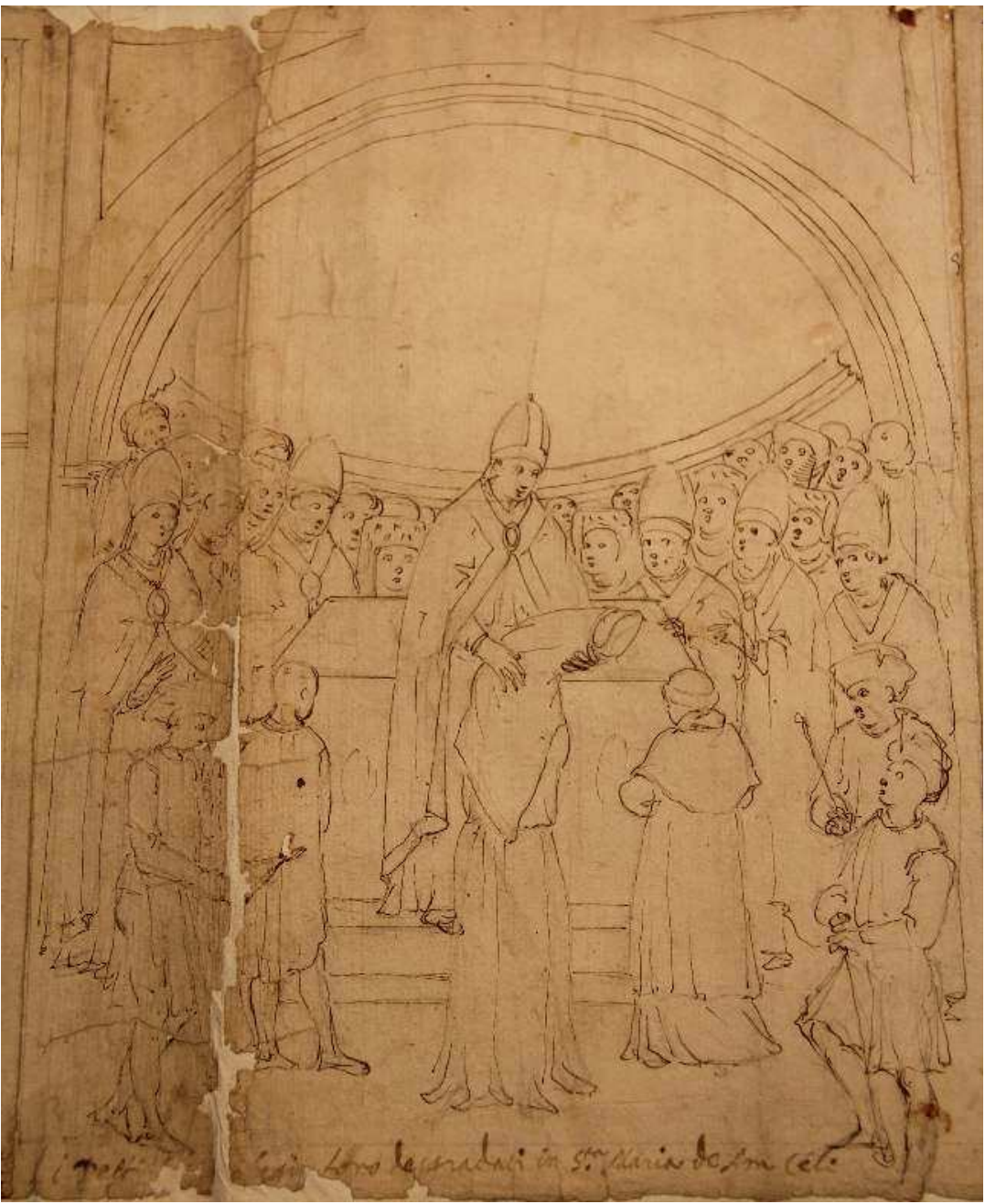

Fig. 17.17 The public removal from office and degradation of the three clergymen at the main altar of Santa Maria di Aracoeli; copy of a fresco cycle (1438-40), formerly in the north transept of the Lateran basilica, roll of pen drawings (end of the sixteenth century) (Archivio Capitolare Lateranense).

devoted to the public removal from office and degradation of the three clergymen by the papal vicar, Andrea da Montecchio, ${ }^{60}$ at the main altar of Santa Maria in Aracoeli (Fig. 17.17). ${ }^{61}$ On the left, the canon Nicola, who has

${ }^{60}$ Andrea da Montecchio, bishop of Osimo (1434-54) is mentioned by Paolo di Lello Petrone: see Magrí, 'La mesticanza', 227.

61 The dismissal from office of the Lateran canon and the two beneficiates also went down in the history of the Franciscan church of Santa Maria in Aracoeli. Padre Casimiro quotes the wording of Paolo di Lello Petrone's 'La mesticanza' along with other public events on the Capitol square, 


\section{CAMBRJDGE}

\section{Cambridge University Press}

978-1-108-83976-1 - The Basilica of Saint John Lateran to 1600

Edited by L. Bosman , I. P. Haynes, P. Liverani

More Information

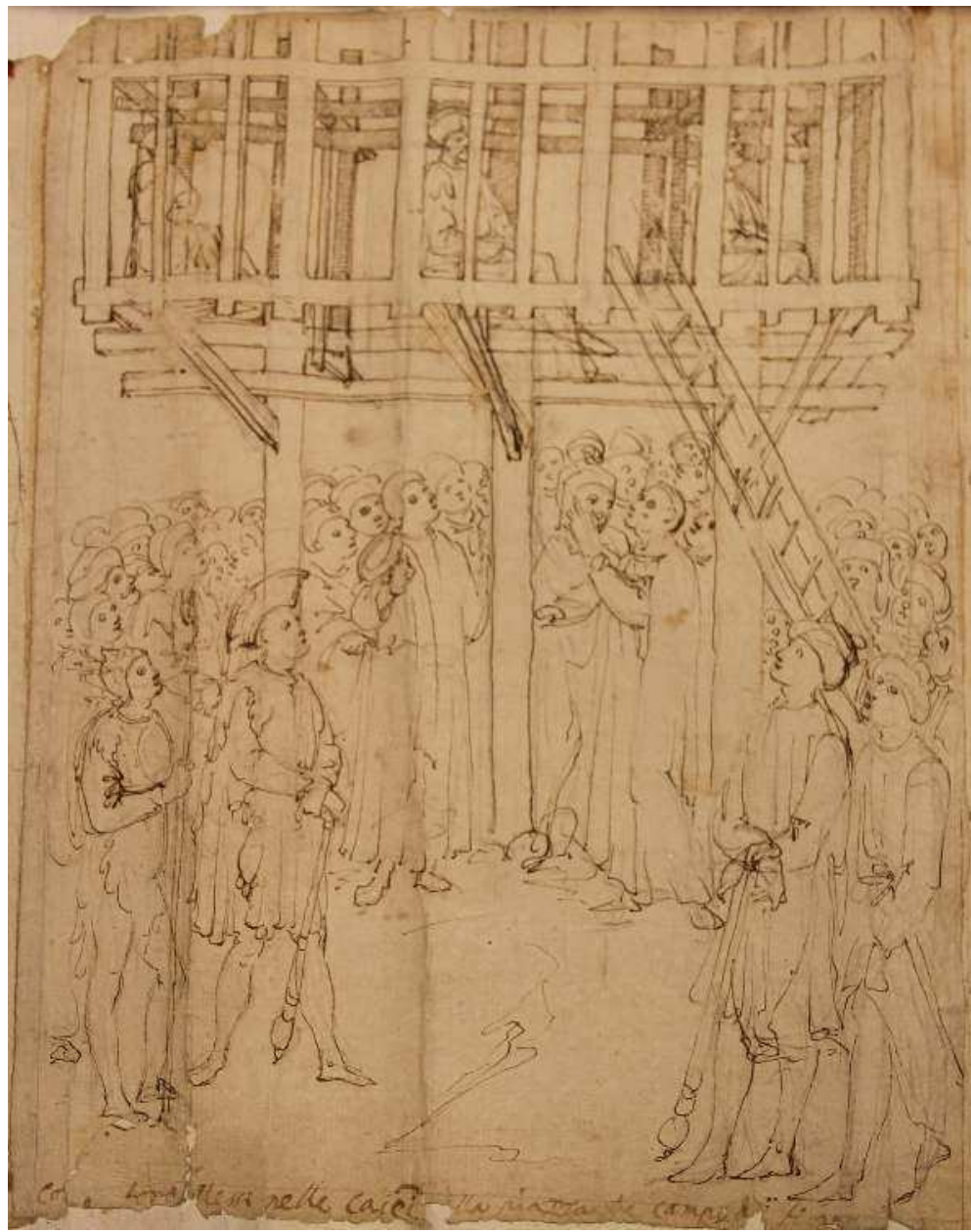

Fig. 17.18 The exposure of the three culprits in the pillory on the Campo dei Fiori; copy of a fresco cycle (1438-40), formerly in the north transept of the Lateran basilica, roll of pen drawings (end of the sixteenth century) (Archivio Capitolare Lateranense).

already had his clerical robes removed, is having the hair of his tonsure cut off; in the centre, one of the two beneficiates is being disrobed, while his partner, on the right with his back towards the viewer, is still awaiting his disrobing and shaving. This is followed by their exposure in the pillory, for

including the burning at the stake of Maria Fenicella, who had been accused of witchcraft, in the period when Bernardino da Siena was preaching in Rome: see P. Casimiro, Memorie istoriche della chiesa e convento di S. Maria in Araceli di Roma (Rome, 1736), 416-18, esp. p. 418. 


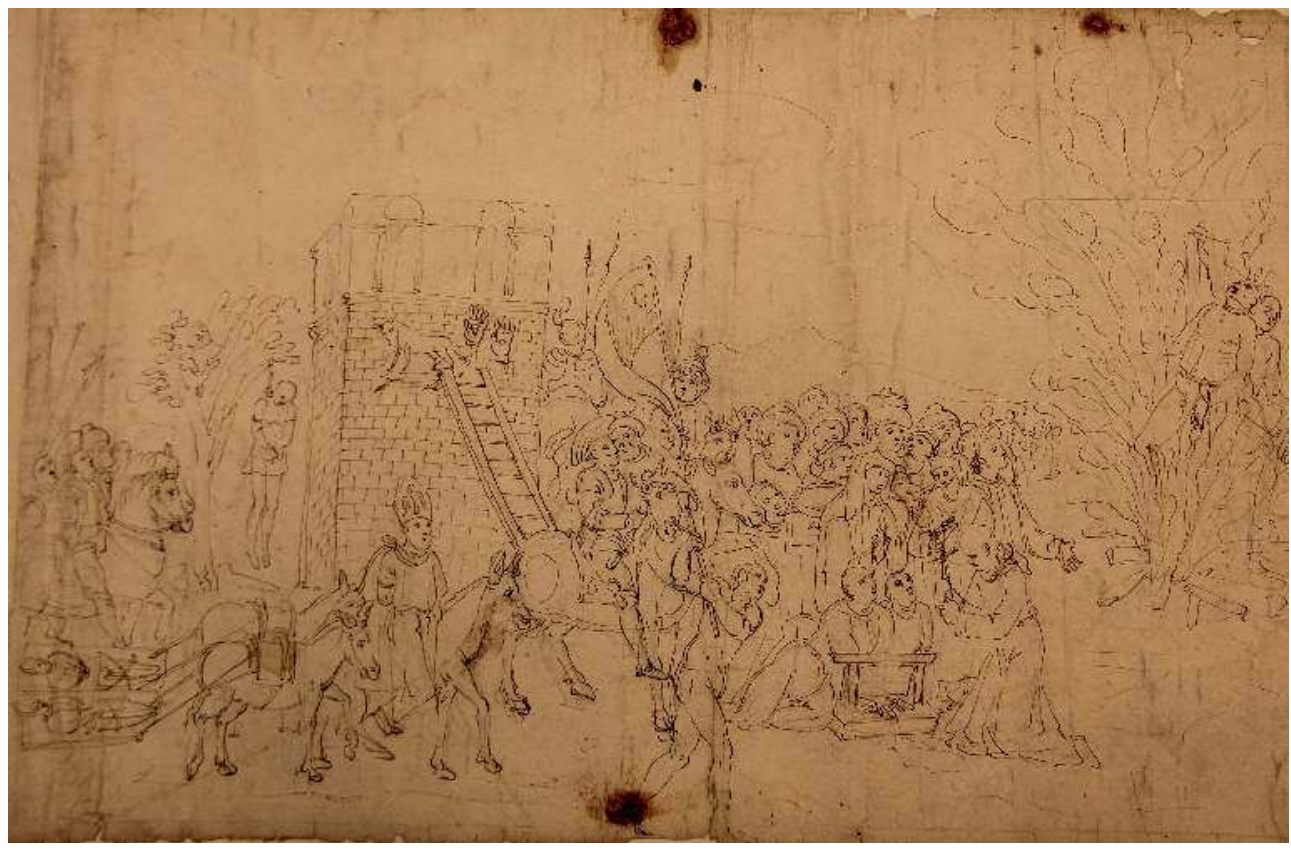

Fig. 17.19 The dragging and public execution of the sacrilegious thieves on the Lateran square in front of the Annibaldi tower; copy of a fresco cycle (1438-40), formerly in the north transept of the Lateran basilica, roll of pen drawings (end of the sixteenth century) (Archivio Capitolare Lateranense).

four days from 4 to 8 September, set high up in a cage on the Campo dei Fiori, followed by a further day on the Capitol (Fig. 17.18). ${ }^{62}$

The next scene shows the procession of disgrace and the humiliating dragging of the evildoers from the Capitol to the Lateran square (Fig. 17.19): the canon is riding on an ass and wearing a 'mitra di carta depenta con doi diavoli in capo ${ }^{63}$ - according to Paolo di Lello Petrone, the mitra infamiae $^{64}$ is clearly recognisable in the copy of the fresco. Capocciola and Garofalo, also wearing mitrae infamiae, were tied to wooden planks and dragged along the ground behind two donkeys. ${ }^{65}$

The right half of the large pictorial field shows the public execution on the Campus Lateranensis, the cruelty of which is described

62 Paolo di Lello Petrone, cited after Magrí, 'La mesticanza', 227.

63 Paolo di Lello Petrone, cited after Magrí, 'La mesticanza', 227.

64 W. J. Connell and G. Constable, 'Sacrilege and redemption in Renaissance Florence: The case of Antonio Rinaldeschi', Journal of the Warburg and Courtauld Institutes 61 (1998), 53-92, at p. 75 .

65 ، ... e li detti Capocciola et Garofalo furon legati in doi tavole et strascinati foro menati dreto a Messer Necola', Paolo di Lello Petrone: see Magrí, 'La mesticanza', 227. 
consistently both in contemporary reports and also in the image. The canon, who had initially disputed his involvement and thus also made himself guilty of perjury, received a 'milder' punishment, since he belonged to a higher rank, and perhaps also because he did not 'directly' lay his hands on the reliquaries: he was hanged from the elm tree on the Lateran square. ${ }^{66}$ By contrast, the executioner first cut off the right hands of the two thieves; ${ }^{67}$ a Capuchin monk in the foreground is holding a cross up in front of the two transgressors to remind them that it was 'an act of penance for the salvation' of their 'sin-stained' souls. ${ }^{68}$ The two chopped-off right hands are seen on the wall of the Annibaldi tower alongside the Capitoline lupa, which served as a symbol of papal justice during the Middle Ages. ${ }^{69}$ Finally, the two evildoers were burnt at the stake, seen on the right edge of the image. According to Dahm, hanging (in contrast to beheading for higher-ranking individuals) was the usual punishment for criminals of the lower ranks or for particularly repellent crimes, while 'burning was rare and tended to be the sentence for extreme heresy or repeated sodomy. ${ }^{70}$

These narrative images show sui generis some of the components of 'pitture infamanti' (images of shame), ${ }^{71}$ as they present the names, deeds, degradation and punishment of the evildoers to contemporaries and their descendants in an iconic fashion in a form of 'visual' pillory. As Samuel Edgerton points out, however, there is a fundamental difference: instead of 'defaming portraits, intended as official punishments of individual persons', the Lateran frescoes are 'pictures of infamous incidents,

66 ، ... Nicola come mero peccatore fu appeso in l'olmo come foro gionti alla Piazza de S. Giovanni': Paolo di Lello Petrone, cited after Magrí, 'La mesticanza', 227. On the hierarchical ranking according to social status and type of offence, see Dahm, Das Strafrecht Italiens, 284-317, esp. pp. 299-305.

67 For the cutting off of the hands, the fresco documents an instrument (mannaia) otherwise used in the quattrocento for decapitations - shown for example in an execution scene on the Capitoline attributed to Ciriaco d'Ancona: see S. Y. Edgerton Jr., Pictures and Punishment: Art and Criminal Prosecution during the Florentine Renaissance (Ithaca, NY, 1985), 152-5 fig. 38.

68 Edgerton, Pictures and Punishment, 131.

69 The site with the she-wolf at the Lateran is described as being a place of justice in the chronicle of Benedict of San Andreas de Soracte, as early as the tenth century: 'in iudicali loco ad Lateranis ubi quidam locus dicitur ad lupam, quae mater vocabatur romanorum, ibi iudiciarum legem finiebat': MGH, Pertz, pp. 720-1 and also p. 712. See also J. Corcopino, 'La louve du Capitole', Bulletin de l'Association Guillaume Budé 4 (1924), 3-19, esp. pp. 10-12.

70 Edgerton, Pictures and Punishment, 135; Dahm, Das Strafrecht Italiens, 301-3.

71 With reference to the definition by Ortalli, who regards the images of shame as being a constitutive element of an iconic, public, official and lay communication system ('elemento interno e costitutivo di un sistema iconico pubblico, ufficiale e laico'): G. Ortalli, ‘ . . pingatur in palatio ... '’ La pittura infamante nei secoli XIII-XIV (Rome, 1979), 280. 
intended to commemorate notorious events', belonging to the genre and to the early history of (political) history painting. ${ }^{72}$ Elements evocative of the secular practice of 'pittura infamante' on public squares and buildings, which was widespread - and equally widely effective - in late medieval communes in Italy were thus present in the form of a narrative depiction in the interior of the Lateran, the mater ecclesiarum. ${ }^{73}$ The north transept was apparently the location used for this type of image in the Lateran church, as the cycle showing the execution of Andreuccio da Peroscia in 1364 already existed there as a precedent.

As Magrì has rightly emphasised, it was customary in the Middle Ages for blood justice proceedings to be conducted in front of the legal symbol of the lupa on the square in front of the north transept façade of the Lateran basilica (until the lupa was moved to the Capitol in 1471) ${ }^{74}$ The square was also the place of assembly in which, according to Paravicini Bagliani, the pontifical rite of excommunication (execrationes in coena Domini) customarily took place, from the Gothic loggia of the Sala del Concilio of the Lateran palace, built by Pope Boniface VIII. ${ }^{75}$

In the mid-fifteenth century the faithful were faced with a spatially complex referential system on high feast days in the Lateran basilica. On the upper storey of the high altar tabernacle, the curtains and shutters were opened. The richly decorated busts of the Apostle Princes behind the secure bars looked down kindly. If the gaze moved right across the west wall of the north transept, those in the know would be able to view, high up on the wall, ${ }^{76}$ the crimes that had been committed against the Apostles'

72 Edgerton, Pictures and Punishment, 77 n. 65, referring for instance to the early Cinquecento narrative panel (Museo Stibbert, Florence) with the 'story of Renaldeschi's blasphemy' against a picture of the Virgin Mary in the church of Santa Maria de' Ricci al Corso in Florence: see Edgerton, Pictures and Punishment, esp. pp. 47-58.

73 The fresco cycle could also be read as a warning to anyone who might attack or insult the papacy, symbolised by the two princes among the Apostles: see J. T. Paoletti and G. M. Radke, Art in Renaissance Italy, 3rd edn (London, 2005), 290.

74 R. Magrí, 'Lupa capitolina', in Nesselrath (ed.), Da Pisanello, 224 (cat. no. 70)

75 In connection with the 'Loggia di giustizia' (lovium) erected on the Capitoline hill by the senators of Rome at the same time, see A. Paravicini Bagliani, 'Bonifacio VIII, la loggia di giustizia al Laterano e i processi generali di scomunica', Rivista di storia della Chiesa in Italia 59 (2005), 377-428, esp. pp. 391-6, 411-13. On the loggia on the Capitoline:

G. B. de Rossi, 'La loggia del comune di Roma compiuta nel Campidoglio l'anno 1299', Bollettino della commissione archeologica comunale di Roma ser. Seconda 10 (1882), 130-40.

${ }^{76}$ Located, according to Infessura: 'si vede la memoria penta come s'entra la ecclesia del santo Ianni ad mano ritta su ad alto': Infessura, Diario, 38. See also Paolo di Benedetto di Cola dello Mastro, cited after R. Magrí, 'Il Memoriale', in Nesselrath (ed.), Da Pisanello, 228. 
reliquaries, and thus against Peter and Paul themselves - as well as the 'just' punishments to which the thieves had been condemned. Would it have been clear to pilgrims from more distant places that the men depicted on the wall, martyred by dragging and burning, were not saints, but rather villains? The possibility of misunderstanding can certainly not be ruled out. The fact that these murals were destroyed in the late sixteenth century under Clement VIII, during renovation of the transept, may be connected with the Counter-Reformation goal of banning such images of iniquity from church interiors and instead disseminating clear messages of salvation. At the same time, the desire to have the paintings documented by a professional draughtsman and to keep the copies in the Lateran archives shows that their - judicial - testimonial quality was still being considered seriously. $^{77}$

77 It can be assumed that an artist working on the redecoration of the transept of the Lateran basilica (directed by Cavalier d'Arpino) was called upon to produce the copies - perhaps Agostino Ciampelli, who worked in Rome on the Lateran baptistery and on the triumphal arch of the Lateran basilica starting from the end of 1594 and in 1596-7: Archivio Storico di Roma (ASR), Camerale I, fabbriche, vol. 1524, S. G. Laterano: 1597 Pagamento a Agostino Ciampelli pittore, 'deve dare a di 25 ottobre scudi 20 di moneta fatto nel mandato al Sg. Gerolamo a Abrusco sono a buon conto delle pitture che fa nell'andito della Cap. S. Giovanni Evangelista .... 20'. I am grateful to Adriano Amendola for this suggestion. 